Illinois State University

ISU ReD: Research and eData

Theses and Dissertations

9-14-2016

\title{
A GIS Analysis of Land Cover Effects on Water Systems: Nutrients and Algae in Stormwater Ponds
}

Nicole Lee Kappel

Illinois State University, nlw92700@gmail.com

Follow this and additional works at: https://ir.library.illinoisstate.edu/etd

Part of the Biology Commons, Environmental Sciences Commons, and the Urban Studies and Planning Commons

\section{Recommended Citation}

Kappel, Nicole Lee, "A GIS Analysis of Land Cover Effects on Water Systems: Nutrients and Algae in Stormwater Ponds" (2016). Theses and Dissertations. 619.

https://ir.library.illinoisstate.edu/etd/619

This Thesis is brought to you for free and open access by ISU ReD: Research and eData. It has been accepted for inclusion in Theses and Dissertations by an authorized administrator of ISU ReD: Research and eData. For more information, please contact ISUReD@ilstu.edu. 


\section{A GIS ANALYSIS OF LAND COVER EFFECTS ON WATER SYSTEMS: NUTRIENTS}

\section{AND ALGAE IN STORMWATER PONDS}

Nicole L. Kappel

66 Pages

Anthropogenic land conversion is occurring rapidly and has the potential to impact our water quality. This study aims to explore the effect of watershed land characteristics on water quality within stormwater ponds (SWPs). Rapid land conversion is known to affect water quality of receiving water bodies, however not much is known about the effect of urbanization on SWPs. Geographic informational systems (GIS) was used to determine areas of land that drain into ponds. Water samples were collected and analyzed for total phosphorous, dissolved reactive phosphorous, nitrate, and ammonia. Algal pigment and percent cover measurements were taken in the field and algal samples were collected for identification to genus in the laboratory. Statistical analysis revealed a negative relationship between ammonia and pondshed area, however no other nutrients or land use characteristics showed significance. Nutrients did not respond to land characteristics examined in this study but algal variables often did respond to land characteristics. Although algal richness was often significantly affected by land use, the relationships were complex and lead us to believe fertilization of lawns may play a role in stormwater ponds. Results from this study may provide insight into urban algal blooms and help guide land management efforts to protect surface water health from nutrient loading due to urbanization.

KEYWORDS: Land use, Stormwater, Pond, Nutrients, GIS, Water Quality, Urban. 


\section{A GIS ANALYSIS OF LAND COVER EFFECTS ON WATER SYSTEMS: NUTRIENTS}

AND ALGAE IN STORMWATER PONDS

NICOLE L. KAPPEL

A Thesis Submitted in Partial Fulfillment of the Requirements for the Degree of

MASTER OF SCIENCE

School of Biological Sciences

\section{ILLINOIS STATE UNIVERSITY}


ㄷ 2016 Nicole L. Kappel 


\section{A GIS ANALYSIS OF LAND COVER EFFECTS ON WATER SYSTEMS: NUTRIENTS}

AND ALGAE IN STORMWATER PONDS

NICOLE L. KAPPEL

COMMITTEE MEMBERS:

Martha E. Cook, Co-Chair

Bill L. Perry, Co-Chair

Catherine M. O’Reilly

Rex J. Rowley 


\section{ACKNOWLEDGMENTS}

Thank you to my committee for all the help throughout my thesis. Bill Perry was very helpful in the development of this project and was there when I needed guidance. Martha Cook's expertise in algal identification and excitement throughout my project was incredibly helpful and appreciated. Catherine O'Reilly was helpful throughout the process in letting me use her lab, equipment, and for helping me when I needed her expertise. Rex Rowley was instrumental toward developing a new methodology for delineation of watersheds and was always willing to help when needed.

Thank you to the Laboratory for Environmental Analysis (LEA) and especially Victoria Heath who not only helped with nutrient analysis of my water samples, but also taught me how to do it myself.

I also would like to thank Kevin Kothe, David Lamb, Bill Jackson, and Troy Olson from the City of Bloomington for allowing me to do research on these ponds, providing me with data, and for taking time to help with this project.

Thank you to Phi Sigma Beta Lambda Chapter for providing me with funding to support this project.

Thank you to my helpers: Nicole McGill, Jessica Drenth, Cara Wilson, and Lucas Kappel. You put on waders and came out to the field with me on some hot and difficult days! Nicole McGill not only helped in the field, but she also helped with algal identification.

Finally, thank you to my family for the support throughout this entire process. Especially, thank you to my sister, Cara, and my husband, Lucas, who are always willing to step in when a helpful hand was needed, you two are incredible and I am so grateful to have you!

N.K. 


\section{CONTENTS}

$\begin{array}{rlll}\text { Page } & \end{array}$

ACKNOWLEDGMENTS

$\begin{array}{ll}\text { CONTENTS ii } & \text { ii }\end{array}$

$\begin{array}{ll}\text { TABLES } & \text { iii }\end{array}$

FIGURES

CHAPTER I: INTRODUCTION 1

CHAPTER II: METHODS $\quad 6$

Sample Collection and Identification $\quad 6$

Water Sample Analysis $\quad 8$

$\begin{array}{lr}\text { GIS Analysis } & 8\end{array}$

$\begin{array}{ll}\text { Statistical Analysis } & 12\end{array}$

$\begin{array}{ll}\text { CHAPTER III: RESULTS } & 15\end{array}$

$\begin{array}{ll}\text { Land Cover and Nutrients } & 15\end{array}$

$\begin{array}{ll}\text { Land Cover and Algae } & 15\end{array}$

$\begin{array}{ll}\text { Nutrients and Algae } & 19\end{array}$

$\begin{array}{ll}\text { Nutrients in Each Pond } & 21\end{array}$

Pre and Post Storm Comparison and Nutrients 23

CHAPTER IV: DISCUSSION 25

$\begin{array}{ll}\text { REFERENCES } & 30\end{array}$

APPENDIX A: SUPPLEMENTARY MATERIALS 38

APPENDIX B: POND AND WATERSHED MAPS 49 


\section{TABLES}

Table

Page

1. GIS Derived and Quantified Land Use Characteristics for Each Pond

2. Analysis of Land Use Variables and Nutrient Concentrations

3. Analysis of Land Use Variables and Algal Variables

4. Analysis of Nutrient Concentrations and Algal Variables 


\section{FIGURES}

Figure $\quad$ Page

1. Ponds and impervious surfaces in Bloomington, IL $\quad 7$

2. GIS workflow 10

3. Pond mean concentration of total phosphorous 21

4. Pond mean concentration of dissolved reactive phosphorous 22

5. Pond mean concentration of ammonia 22

6. Pond mean concentration of nitrate 23

7. Pre and post storm ammonia concentrations 24

8. Pre and post storm total phosphorous concentrations 24 


\section{CHAPTER I: INTRODUCTION}

Anthropogenic land conversion has affected the world dramatically (Rockstrom et al. 2009, Steffen et al. 2015). Humans have been converting natural landscapes for agricultural use for thousands of years. Agricultural land is characterized by the removal of vegetation within an area and the addition of crops or livestock (Ramankutty and Foley 1999, Olofsson and Hickler 2008). Within a natural landscape, vegetation is diverse and allows for nutrient removal during the infiltration of water. Within an agricultural landscape, fewer nutrients are removed and due to fertilizer treatments, more nutrients are added. Agricultural areas are potentially a large hazard to downstream water quality and have profound effects on receiving water bodies such as the Gulf of Mexico (Mitsch et al. 2001). Deforestation and clear cutting for timber is another example of land conversion. Streams in a clear-cut watershed may exhibit a fivefold increase in nitrate compared with streams in a natural watershed (Likens et al. 1969). The loss of vegetation also removes shading and causes increased water temperature (Brown and Krygier 1970) which affects the survival, growth rate, and production of toxins of organisms including algae (Williamson et al. 2010, Carey et al. 2012, Ekvall et al. 2013, Childress et al. 2016). More recently, an extensive alteration of landscape has included urbanization and suburbanization. Urbanization has been associated with degradation of water quality (U.S. EPA 2016), and the addition of impervious surfaces increases nutrient concentrations and algal biomass in streams (Hatt et al. 2004, Buesse 2006). The effect of urbanization on stormwater ponds has not been studied much, but is becoming a more prevalent focus of research due to the link between urbanization and water degradation.

The trend of increasing urbanization and suburbanization worldwide has potential to impact water flow and the water quality of streams, lakes, wetlands, and constructed ponds (Paul 
and Meyer 2001, Lewitus et. al. 2003, Bernhardt and Palmer 2007, Greenway 2007).

Suburbanization and urbanization result in changes to land characteristics of watersheds that alter the flow of water that drains into receiving waterways (Carr et al. 2005). Urban and suburban systems utilize a network of storm sewers to deposit flood water into ponds and other waterways (Bernhardt et al. 2008). Changes in water flow due to increases in impervious surfaces (such as roads and sidewalks) as well as other land characteristics (such as fertilizer applications and storm sewers) may cause increased nutrient loading to receiving waters (Johnson et al. 2011, Dietz 2007, Strecker and Quigley 2001). Increased nutrient loading typically leads to increased algal biomass not only in the receiving waterways, but also in downstream systems including marine waters. Many marine systems (e.g., Gulf of Mexico (Brezonik et al. 1999, Mitsch et al. 2001)), and larger lakes (e.g., Lake Erie (Michalak et al. 2013)) experience algal blooms that lead to dead zones due to the inflow of nutrient loaded waters. Studies of streams and ponds have shown that urbanization may increase nutrient concentrations, pollutants, algal growth, water temperature, conductivity, and the presence of harmful algal genera (Paul and Meyer 2001, Hatt et al. 2004, Busse et al. 2006, Hoellein et al. 2011, Johnson et al. 2011, Klose et al. 2012, Fitzgerald et al. 2012, Stevenson et al. 2012, Ekvall et al. 2013, Hester and Bauman. 2013, Stearman and Lynch 2013, Pennino et al. 2014, Drerup and Vadeboncoeur 2016). There has been less focus on urban stormwater ponds (SWPs) than streams and other bodies of water.

As suburban and urban areas spread, stormwater ponds (SWPs) are becoming more common because the abundance of impervious surface in urban and suburban areas increases the severity and likelihood of flood events (Hollis 1975). SWPs are man-made structures that are intended to mitigate downstream flooding events. SWPs may be either retention or detention basins, but for the purpose of this study SWPs refer to wet bottom detention basins exclusively. 
Wet bottom detention basins hold a base amount of water at all times and therefore do not experience dry periods (pers. Kothe). SWPs decrease flooding events by intercepting water from storm sewers and temporarily retaining floodwaters, thereby decreasing downstream flooding (Hogan and Walbridge 2007). Although urban and suburban ponds are commonly used to prevent flooding, it is not yet well understood what ecological role they may play (Vincent and Kirkwood 2014). There is evidence to support that stormwater ponds have the potential to reduce downstream nutrient concentrations and total suspended solids (TSS) (Borden et al. 1997, Mallin et al. 2002). Furthermore, watershed land characteristics may affect the quantity and ratio of nutrients entering the ponds while processes in a stormwater pond may affect nutrient quantities and ratios released from the pond, thereby affecting water quality further downstream (Hatt et al. 2004, Zhu et al. 2004).

A true watershed is defined as having one point through which all water drains (one pour point) but a SWP does not follow this pattern. Rather, the complete watershed can be divided into two categories, the pondshed and the sewershed, each of which contains numerous pour points through which water can enter. The pondshed is the area that drains the surface of the land area surrounding the border of a natural or stormwater pond. The sewershed is the area that runs onto impervious surfaces, is channeled through the storm sewer system, and enters the stormwater pond. The presence of a sewershed complicates and alters the water flow within urban systems, especially since water that is deposited through the sewer-system is often not naturally part of a ponds watershed. Delineation of complete watersheds may be done using geographic informational systems (GIS). Once the watershed has been determined, land characteristics can be analyzed and compared to water quality in a SWP. 
Changes in land characteristics have the potential to alter the concentration and ratio of nitrogen $(\mathrm{N})$ and phosphorous $(\mathrm{P})$ in runoff (Klose et al. 2012). Fertilizers applied to lawns in excess or right before a storm may be transported onto roadways, altering nutrient concentrations in SWPs. Pet waste and dirt also may be a source of nutrients in SWPs (U.S. EPA 1999). Increase in nutrients within receiving waterways impact the algae, fish, and macroinvertebrates found within those systems (Busse et al. 2006, Williams et al. 2003). Nutrient concentrations are known to change algal community composition and generally increase the growth of algae found in receiving water bodies.

Algae are photosynthesizing mostly aquatic protists or cyanobacteria that are usually limited by the amount of phosphorous $(\mathrm{P})$ in freshwater systems, including stormwater ponds (Graham et al. 2009). In freshwater systems with excess nitrogen inputs, green algal populations are most prevalent, but in systems with excess phosphorus, $\mathrm{N}$-fixing cyanobacteria dominate (Stancheva et al. 2013). An algal bloom is an excess amount of algae populating a water body and is typically due to nutrient loading. Anabaena and Microcystis are commonly observed toxin producing cyanobacteria that occur in blooms within the Midwest when the N:P ratio drops to favor such cyanobacteria. While most algal genera do not pose a problem in terms of toxicity, algae blooms may be a problem for aquatic organisms and are considered a nuisance to humans due to 'unsightly' growth on surface waters (O'Farrell et al. 2012, Zamyadi et al. 2013). Temperature and nutrient concentrations may affect the algal community and cause a shift toward bloom formers that produce toxins (Ekvall et al. 2013).

Due to the increase in urban areas and the connectivity of waterways, it is important to understand what land characteristics relate to changes in nutrients and algae. Knowing what affects water quality may assist in urban planning efforts as well as improve the health and 
quality of water. This study explores the link between land characteristics, water quality, algae biomass, and algae composition in SWPs. We hypothesized that the land characteristics examined would affect the nutrients and algae in SWPs. Land use characteristics considered include: watershed size, sewershed size, pondshed size, impervious surface area (ISC area), percent impervious surface (\%ISC), storm sewer pipe length, and number of inlets. Furthermore, we expected that land characteristics would be similarly capable of predicting algal patterns as nutrients are. Algal parameters examined include: percent cover attached algae, percent cover surface algae, ash-free dry mass, chlorophyll-a pigment, phycocyanin pigment, and genera present. Finally, we expected that storm events would result in an increase in nutrient concentrations within SWPs. 


\section{CHAPTER II: METHODS}

\section{Sample Collection and Identification}

Eighteen wet-bottom detention basins in Bloomington, Illinois were sampled every other week in 2015 from April-September (Figure 1). Each pond is owned and maintained by the City of Bloomington. Water samples were obtained near shore in a 1-liter bottle that was rinsed 3 times with sample water and filled. Water samples were frozen within 24 hours of collection for future analysis. In addition, a YSI EXO1 Sonde was calibrated on the morning of each collection day and used to collect data on: dissolved oxygen (ODO \% and ODO $\mathrm{mg} / \mathrm{L}$ ), specific conductivity (SPC), temperature $\left({ }^{\circ} \mathrm{C}\right)$, chlorophyll-a pigment (RFU), and phycocyanin pigment (RFU). While chlorophyll-a is present in all algae, phycocyanins are found only in cyanobacteria, cryptomonads, glaucophytes, and freshwater red algae. In most cases, phycocyanin can be used to indicate the presence of cyanobacteria.

On each sampling date at each pond, percent cover of attached algae, surface algae, and macrophytes were estimated within a $53 \mathrm{~cm} \times 53 \mathrm{~cm}$ quadrat placed at three random locations in the general area from which the water sample was taken. A Whirl-pak was used to take a representative sample of algae observed in each quadrat if the average percent cover was greater than 5\%. Water samples and algae samples were stored in a cooler on ice until transported to the laboratory. Whirl-paks were opened and stored in a refrigerator at $10^{\circ} \mathrm{C}$ for no more than 48 hours prior to observation and identification of the algae. A representative slide of each algae sample was prepared and observed using an Olympus BX-60 compound light microscope. All algae present were identified to genus utilizing Prescott's (1978) key and organized by major monophyletic group to aid with interpretation of algal pigment data. 


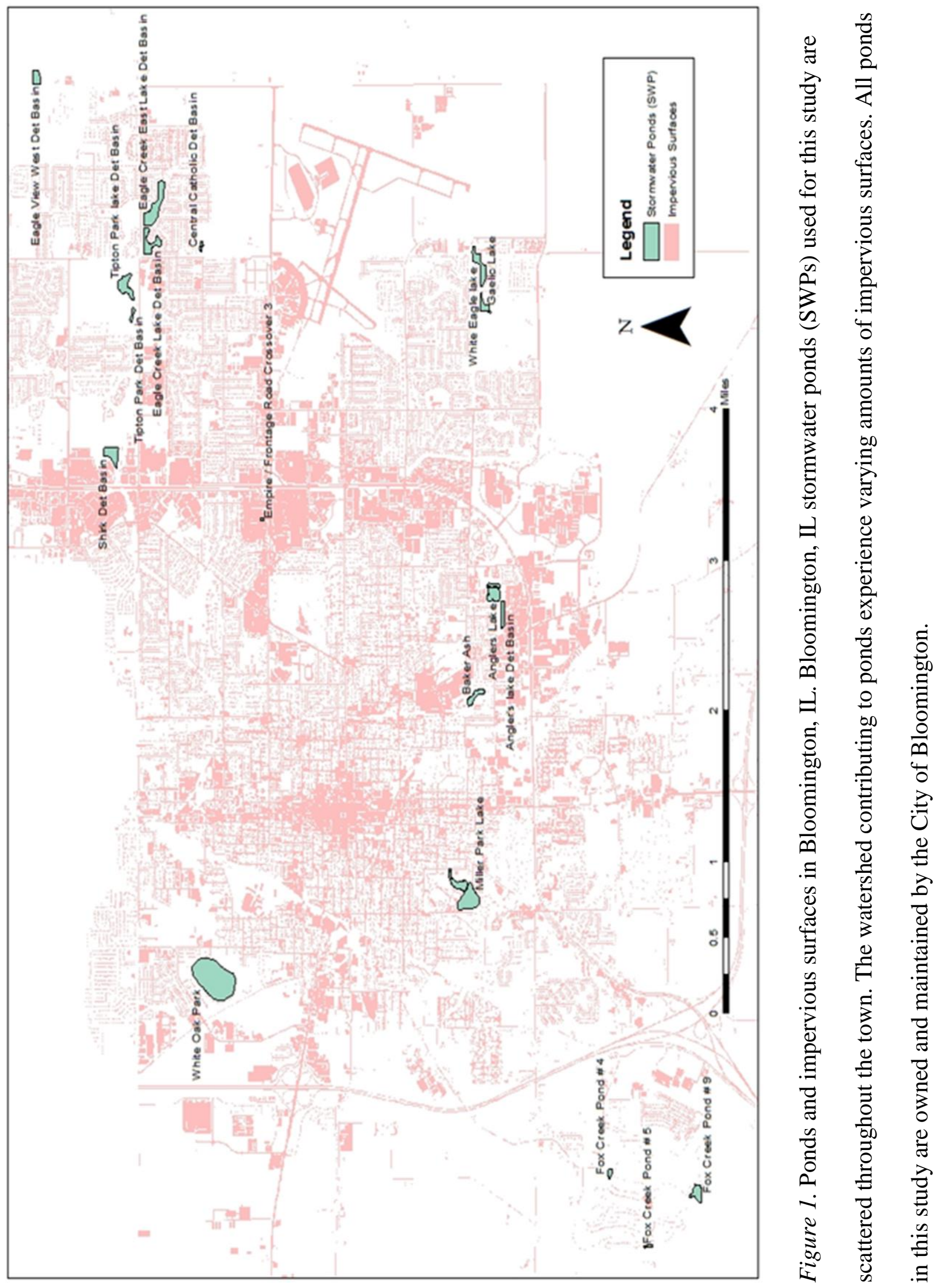




\section{Water Sample Analysis}

The 1-liter water sample taken at each site was processed for total suspended solids (TSS), total phosphorous (TP), and dissolved reactive nutrients (DRN) including nitrate $\left(\mathrm{NO}_{3}\right)$, ammonia $\left(\mathrm{NH}_{3}\right)$, and dissolved reactive phosphorous (DRP). To test for $\mathrm{TP}$, a $40 \mathrm{~mL}$ of unfiltered sample was frozen, digested, and then analyzed on the Lachat Flow Injection Analysis System (FIA) using method 10-115-01-4-C. To test for DRN, a known volume of water was filtered through a $45 \mathrm{~mm}$ diameter, $0.45 \mu \mathrm{m}$ pre-ashed, pre-weighed filter and frozen until analyzed on the FIA for DRP (method number 10-115-01-1-M), $\mathrm{NH}_{3}$ (method number 10-107-06-1-Q), and $\mathrm{NO}_{3}$ (method number 10-107-04-2-A). Filters were saved to determination of total suspended solids (TSS).

To determine Total suspended solids (TSS), filters were weighed prior to use for water filtration. After filtration, filters were dried at $100^{\circ} \mathrm{C}$ for at least 24 hours, weighed again and placed in an oven at $540^{\circ} \mathrm{C}$ for 6 hours and weighed a third time. The difference between the $540^{\circ} \mathrm{C}$ weight and the $100^{\circ} \mathrm{C}$ weight is the total amount of organic sediments of the sample (ashfree dry weights).

\section{GIS Analysis}

A combination of data layers from the City of Bloomington (COB), National Map, and 2.5ft 32bit Illinois LiDAR derived datasets were used in ArcGIS version 10.3.1 to delineate watersheds as well as address spatial questions regarding watershed attributes. COB layers were in the standard Illinois State Plane East projected coordinate system. All other layers were reprojected to be consistent with the $\mathrm{COB}$ layers. Many COB layers were incomplete, therefore 
aerial imagery provided by the COB along with the ESRI basemap imagery were used to digitize impervious surfaces and inlet locations within each pond watershed.

To determine sample sites, the COB pond layer was utilized. All ponds that were classified as wet detention basins owned and maintained by the city were extracted. Each extracted pond was then examined and determined to be accessible or not. There were eighteen stormwater ponds (SWPs) that were accessible by car in this study (Figure 1).

A modified d8 method (Tribe 1992) was used to delineate watersheds. The d8 method involves making a flow direction layer to identify any sinks within the digital elevation model (DEM) layer and filling those sinks. Unfortunately, several ponds were identified as sinks and were then filled in and resulted in several inaccurate watersheds. To address this problem, values that represented ponds in the sink layer were identified and then reclassified as nonsink pixels thereby allowing the pond values to remain unfilled. A conditional statement was then utilized to determine that if the pixel in the layer was a pond. The watershed tool would use the unfilled DEM and if any other pixel type it would use the filled DEM. Another flow direction and flow accumulation layer was generated from this corrected DEM and a watershed was then delineated. Due to the extreme precision of the LiDAR data, the fill tool over-flattened the landscape for some watersheds and it became necessary for the unfilled DEM to be used for delineation of the watershed for some ponds. 


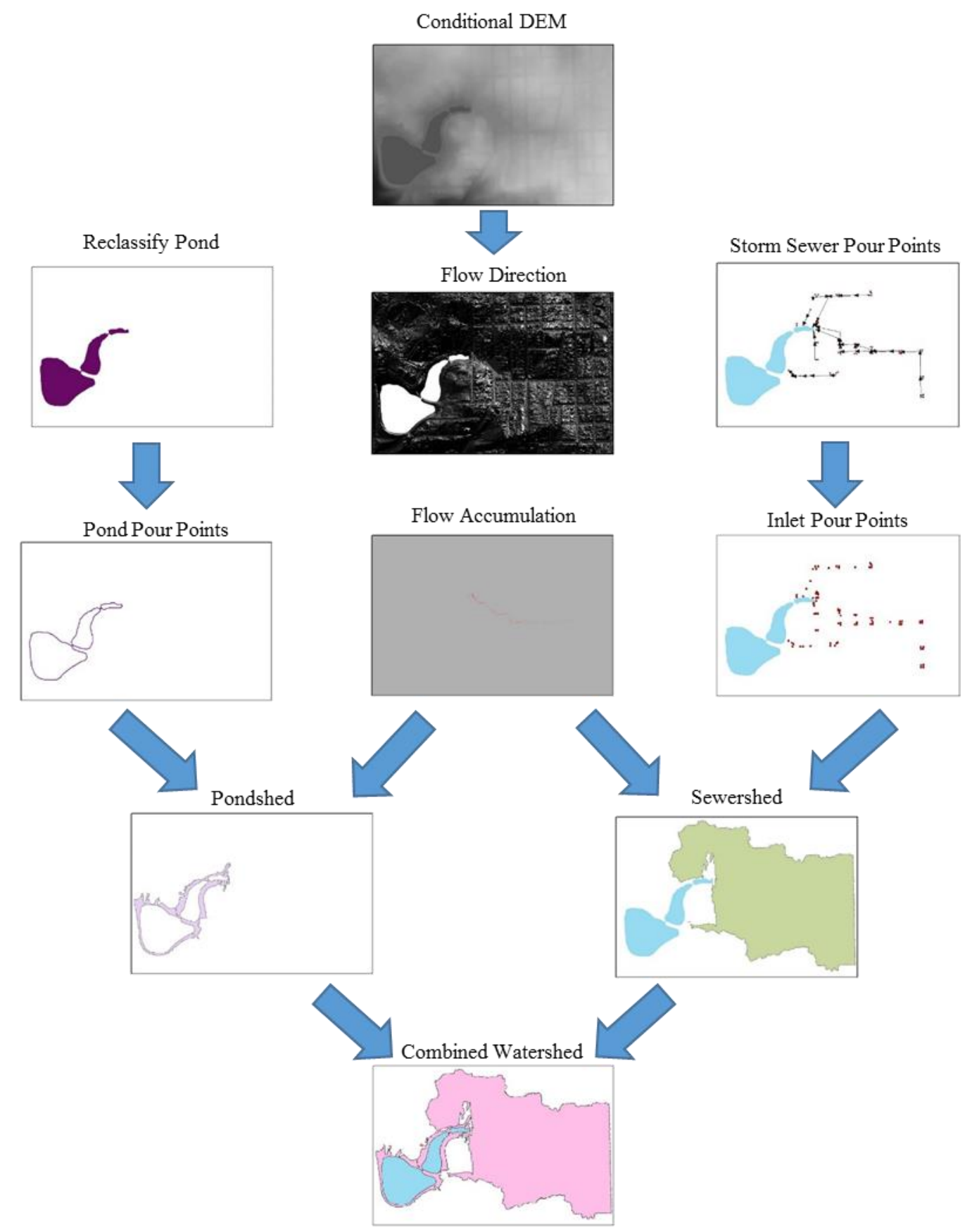

Figure 2. GIS workflow. GIS delineated pondsheds were produced by reclassifying the pond that was identified as a sink, using the border as pour points and the conditional DEM as the elevational model. Sewersheds were produced by identifying storm sewer inlets as pour points. The pondshed and sewershed could then be merged to determine the overall watershed 
To identify the total watershed, two subwatersheds were determined for each pond based on the border of the pond and the anthropogenically altered watershed contributing to the pond through the storm sewer system (Figure 2). In order to delineate a watershed, pour points must be established. The border of the pond itself was used as a set of pour points for the watershed of the pond (pondshed). Pour points for pondsheds utilized the ponds that were identified as a sink, or points toward which water would flow, while processing the digital elevation model (DEM). Only the boundary of the polygon being considered as the pondshed pour points in order to minimize processing time as well as to minimize errors within the software. These pour points were snapped, or moved to a location on the DEM that would enable flow modeling, and used to create the appropriate pondshed layer.

The sewer inlets were used as the pour points for the watershed of the land area emptying into the storm sewer and then into the pond (sewershed). Determining which inlet points were relevant to each pond required tracing each storm sewer from pond to inlet and extracting all these for each pond. Each inlet was the extracted if it was connected to this storm sewer system. These inlet points were snapped and used to delineate the sewershed. Once both pondsheds and sewersheds were delineated, the resulting rasters were merged into one watershed. This was done by converting each from raster to polygon without simplifying edges. These polygons were then merged and converted back from feature to raster. This final watershed was used for all resulting analyses.

Some issues arose while implementing the basic protocol described. One issue occurred when a pond was not identified as a sink. This was addressed by utilizing the COB digitized pond feature. This also caused problems in which the pondshed would extend into the pond 
rather than only to the land area surrounding it. This problem was addressed by reclassifying any pondshed that lay within the pond to be NoData. This problem arose for pond 2, 8, and 12 .

Another problem was that some computed sewersheds were overextended or not extended enough from their actual bounds given the terrain. For these watersheds, several attempts were made to change the snap-pour-point distance or use different DEMs (filled, unfilled, aggregate, or combination). None of these methods worked for these watersheds, so a hillshade with a z-factor of 10 was generated and then used to manually digitize the sewershed. Land characteristics that were used for statistical analysis included: watershed area, sewershed area, pondshed area, impervious surface area (ISC area), impervious surface percent (\%ISC), pipe length, and number of inlets. Watershed, sewershed, pondshed, and ISC area was determined by the count of pixels found in the attribute table and multiplied by the area of the pixel. Percent impervious surface was determined by dividing ISC area by watershed area. Pipe length was determined by the extracted sewershed network for a pond and using the sum in the summary statistics of the attribute table. Number of inlets was determined by the count in the attribute table. A summary of the quantified land use characteristics shows there is a variation in traits between ponds (Table 1).

\section{Statistical Analysis}

JMP12 was used to determine relationships between data collected in the field, obtained from the lab, and data from GIS analysis. Regressions of the means of data for each pond was run for the whole season, and then split up into the season. Prior to each regression, variables were checked for normality and either log or square root transformed to correct for any failure of the assumption. Each bivariate plot was run for the mean of all data collected (overall mean), the 
mean of all data collected for all seasons (seasonal unsorted), and the mean for each calendar season individually (spring or summer mean). 


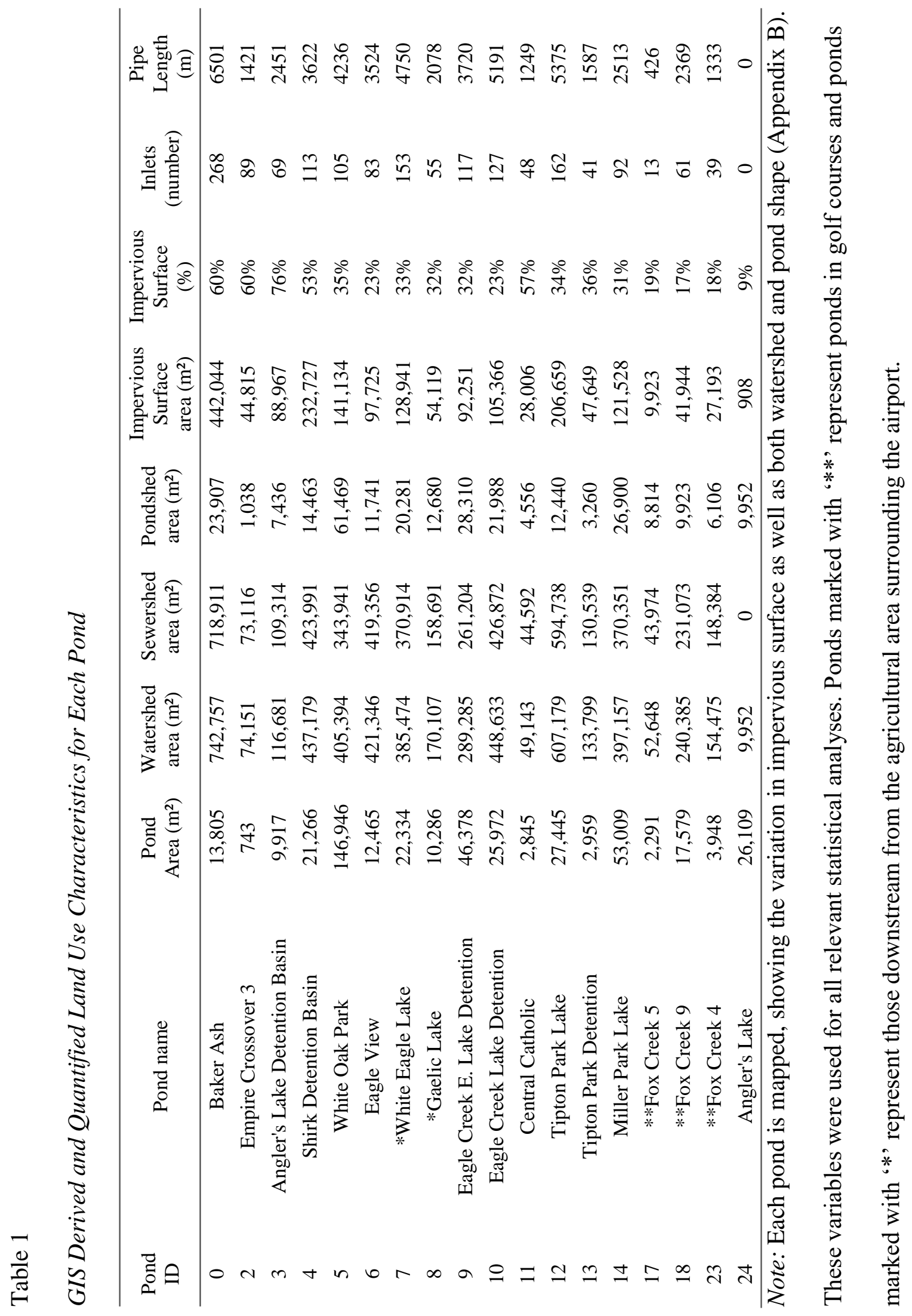




\section{CHAPTER III: RESULTS}

\section{Land Cover and Nutrients}

Land characteristics determined through GIS varied between ponds (Table 1). Pondshed area was negatively related to $\mathrm{NH}_{3}$ concentrations when considering the mean of the seasonal means as well as just the spring means (Table 2). There were no significant correlations between any other land use characteristics or nutrients.

Table 2

Analysis of Land Use Variables and Nutrient Concentrations

\begin{tabular}{cccccccc}
\hline $\begin{array}{c}\text { Nutrient } \\
\text { Variable }\end{array}$ & $\begin{array}{c}\text { Watershed } \\
\text { area }\left(\mathrm{m}^{2}\right)\end{array}$ & $\begin{array}{c}\text { Sewershed } \\
\text { area }\left(\mathrm{m}^{2}\right)\end{array}$ & $\begin{array}{c}\text { Pondshed } \\
\text { area }\left(\mathrm{m}^{2}\right)\end{array}$ & $\begin{array}{c}\text { Impervious } \\
\text { Surface } \\
\text { area }\left(\mathrm{m}^{2}\right)\end{array}$ & $\begin{array}{c}\text { Impervious } \\
\text { Surface } \\
(\%)\end{array}$ & $\begin{array}{c}\text { Inlets } \\
(\text { number })\end{array}$ & $\begin{array}{c}\text { Pipe } \\
\text { Length } \\
(\mathrm{m})\end{array}$ \\
\hline $\mathrm{TP}$ & $\mathrm{NS}$ & $\mathrm{NS}$ & $\mathrm{NS}$ & $\mathrm{NS}$ & $\mathrm{NS}$ & $\mathrm{NS}$ & $\mathrm{NS}$ \\
$\mathrm{DRP}$ & $\mathrm{NS}$ & $\mathrm{NS}$ & $\mathrm{NS}$ & $\mathrm{NS}$ & $\mathrm{NS}$ & $\mathrm{NS}$ & $\mathrm{NS}$ \\
$\mathrm{NO}_{3}$ & $\mathrm{NS}$ & $\mathrm{NS}$ & $\mathrm{NS}$ & $\mathrm{NS}$ & $\mathrm{NS}$ & $\mathrm{NS}$ & $\mathrm{NS}$ \\
$\mathrm{NH}_{3}$ & $\mathrm{NS}$ & $\mathrm{NS}$ & $\mathbf{0 . 0 0 9 9}, \mathbf{- 0 . 3 5}$ & $\mathrm{NS}$ & $\mathrm{NS}$ & $\mathrm{NS}$ & $\mathrm{NS}$ \\
\hline
\end{tabular}

Note: Separate linear regressions for the overall mean nutrient concentration, spring mean nutrient concentration, and summer mean nutrient concentration were analyzed. The only statistically significant result was observed when correlating pondshed area to the $\mathrm{NH}_{3}$ concentration in spring. Data in table follows the format $\mathrm{p}$ value, $\mathrm{R}^{2}$ value.

\section{Land Cover and Algae}

Land use changes were related to variations in algal measurements. The total watershed area had a positive significant relationship to the number of green algal genera observed when considering the overall seasonal means and the summer means (Table 3). Sewersheds were positively related to the number of green algal genera when considering the mean of all data 
points collected (Table 3). The impervious surface area measurements within watersheds were negatively related to the number of diatom genera observed for the overall seasonal mean and the summer means (Table 3). Pipe length positively correlated with phycocyanins in the water column in the spring and the number of green algal genera observed in the summer (Table 3).

Due to small sample size, several statistically significant regressions were not included. Some statistically significant findings include overall mean percent cover macrophytes vs pondshed area, summer mean percent cover macrophytes vs pondshed area, spring mean number of cyanobacteria observed vs number of inlets, and spring mean number of cyanobacteria observed vs ISC area. Finally, the fall mean chlorophyll-a vs pondshed area was statistically significant but due to only having one sampling date, were excluded. 


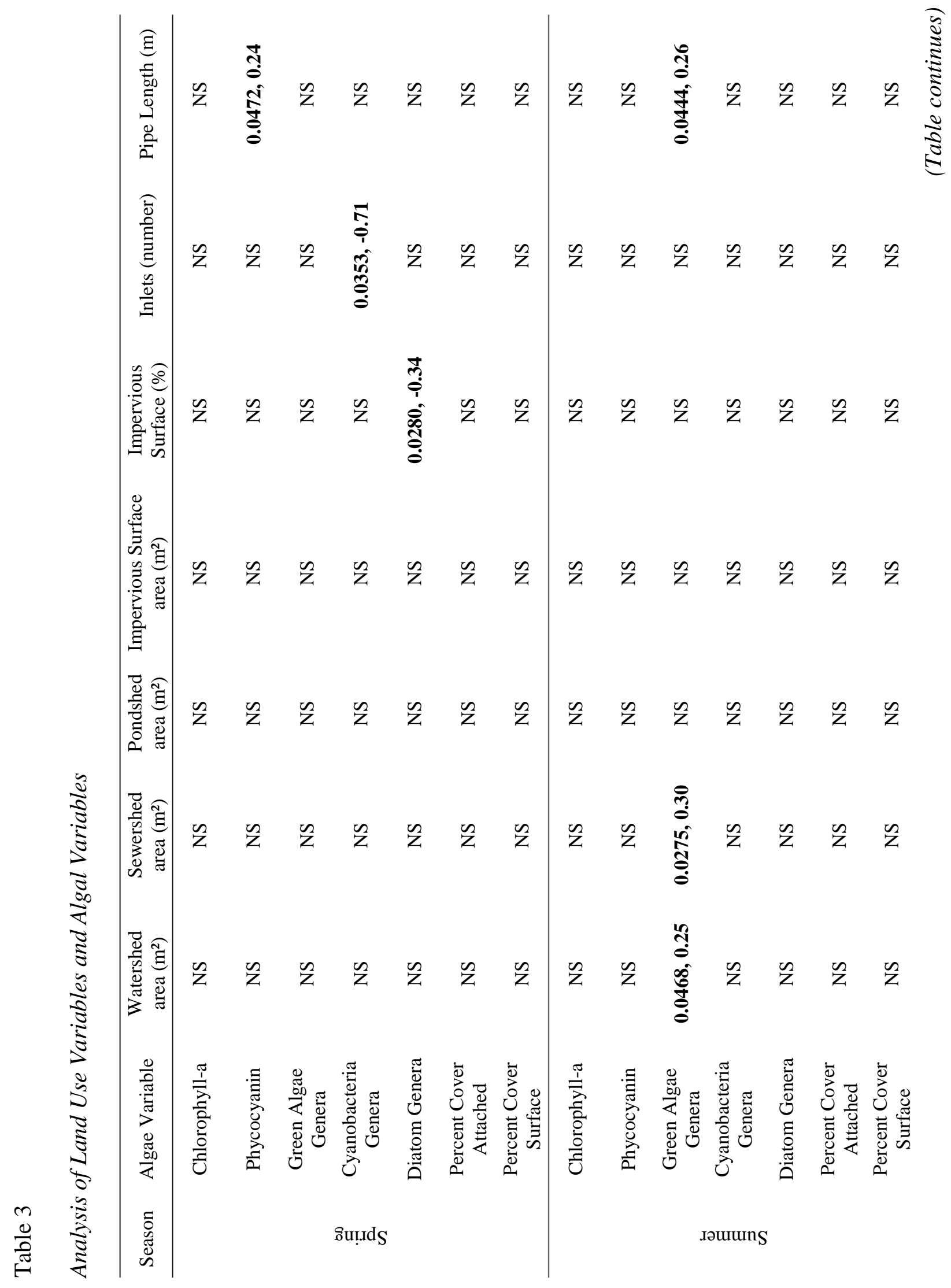




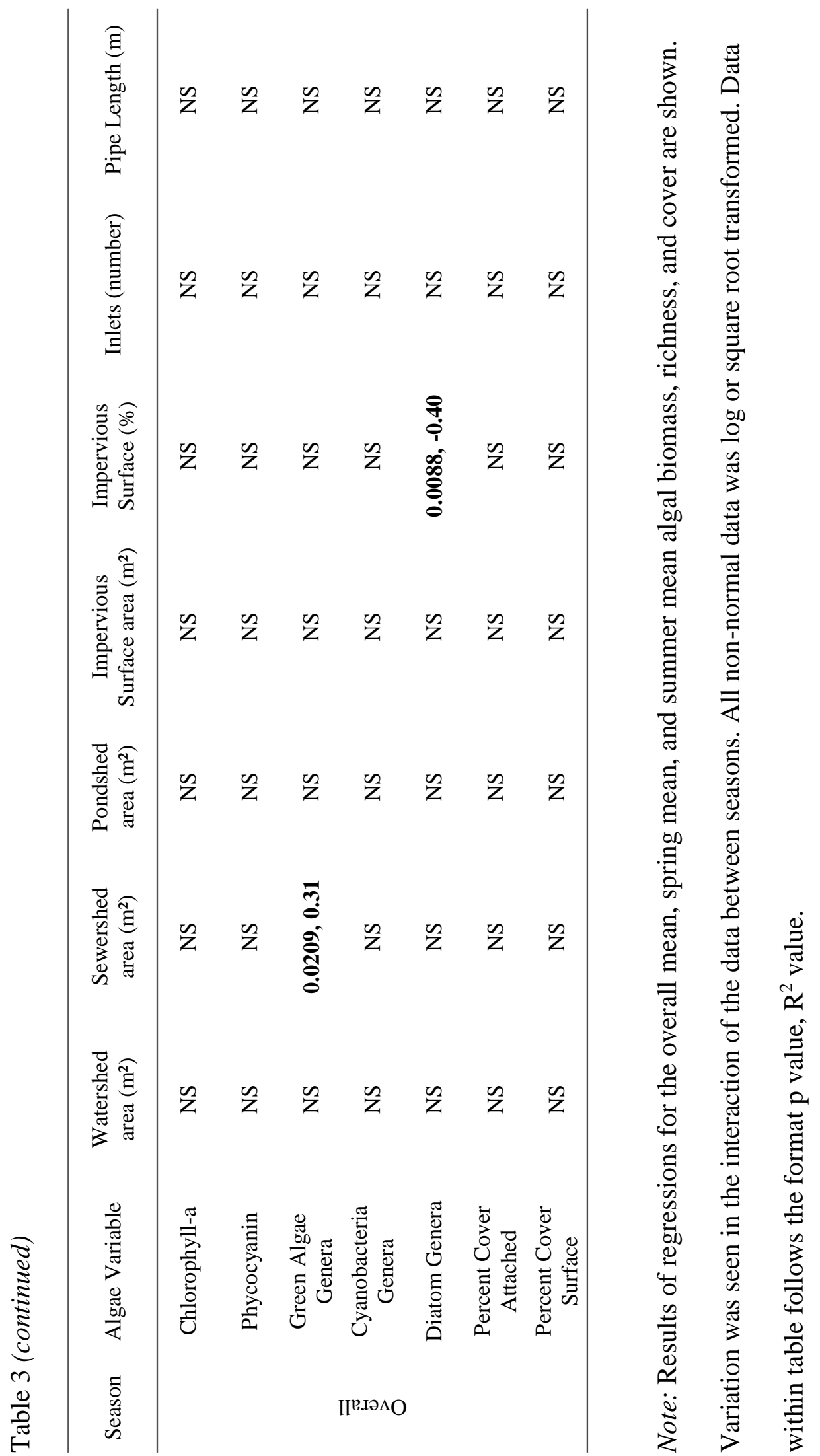




\section{Nutrients and Algae}

This study showed that changes in several nutrients may have a significant relationship to

changes within algal variables. Ammonia $\left(\mathrm{NH}_{3}\right)$ exhibited a positive relationship with the overall mean number of cyanobacteria genera observed as well as the mean number of green algae genera and cyanobacteria genera observed in the summer (Table 4). Nitrate $\left(\mathrm{NO}_{3}\right)$ showed a statistically significant positive correlation with the number of diatom genera when considering the overall mean, the spring mean, and the summer mean (Table 4). Nitrate $\left(\mathrm{NO}_{3}\right)$ also had a negative significant relationship to the overall seasonal mean number of cyanobacteria genera observed (Table 4).

The concentration of DRP had a positive significant correlation to the overall mean number of diatom genera observed in each pond and the overall mean percent cover of attached algae at each site (Table 4). TP concentrations were positively significantly related to chlorophyll-a and phycocyanin pigments in the water column when considering the overall mean, the overall seasonal mean, the spring mean, and the summer mean (Table 4). 


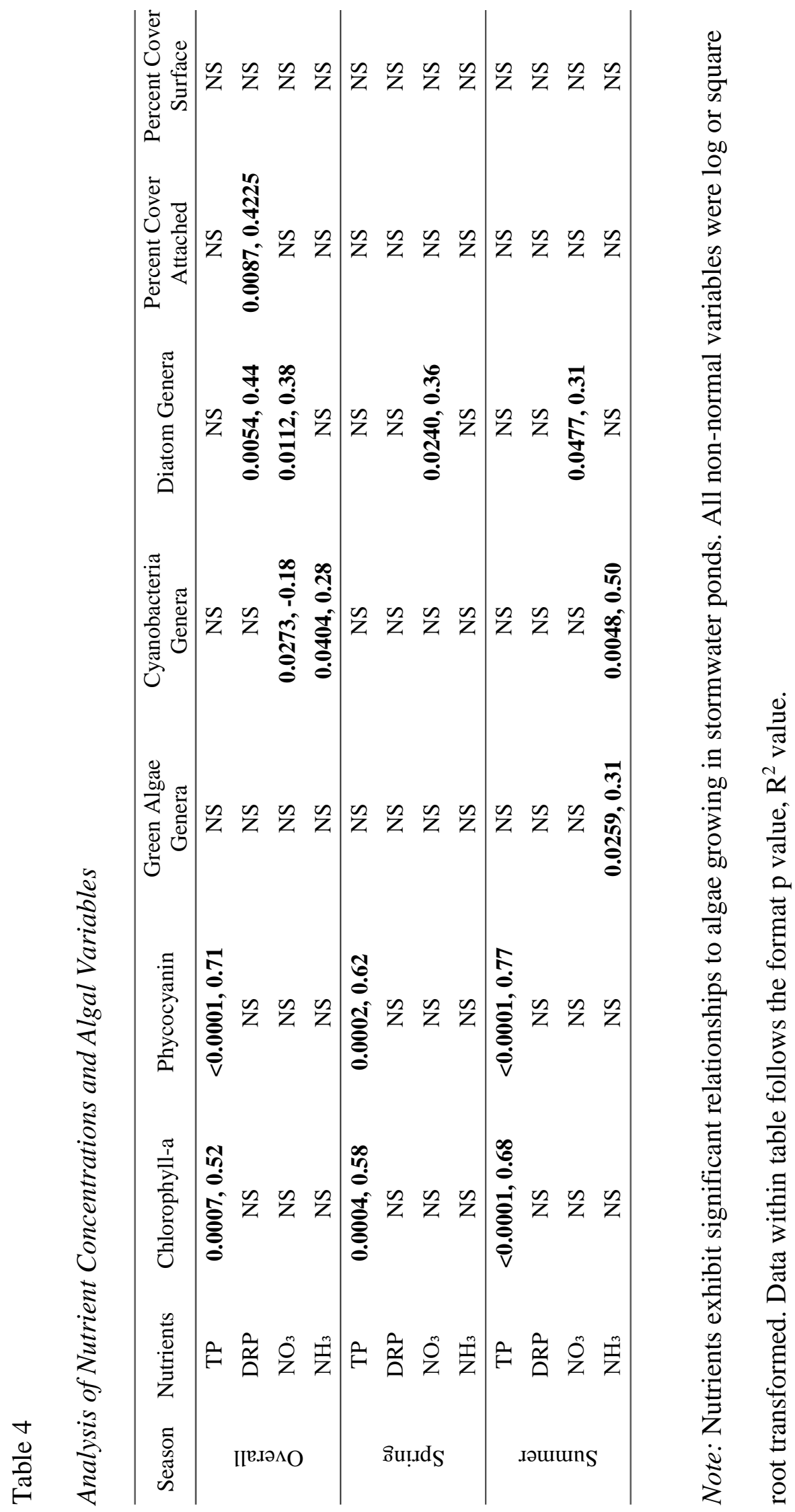




\section{Nutrients in Each Pond}

Changes in nutrient concentrations were observed between ponds as well as over time. Phosphorous and Nitrogen varied in concentration throughout the season as one would expect. The overall mean concentration of TP (Figure 3), DRP (Figure 4), $\mathrm{NH}_{3}$ (Figure 5), and $\mathrm{NO}_{3}$ (Figure 6) for each pond also varies.

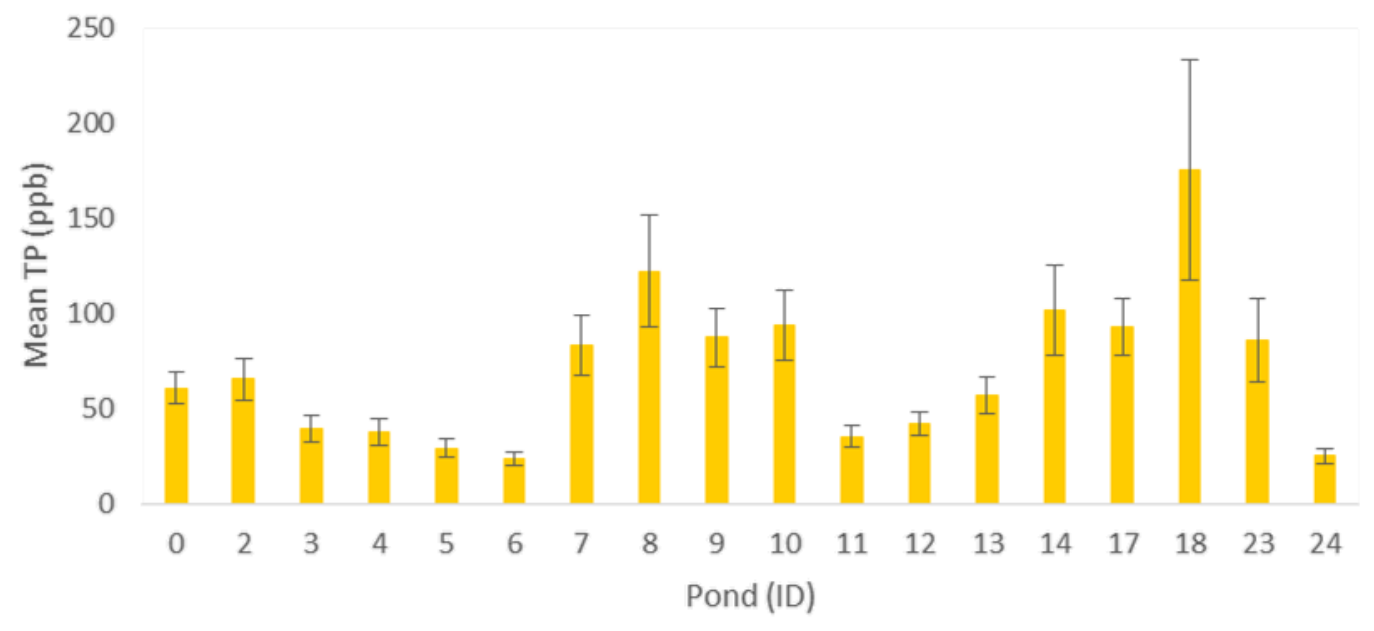

Figure 3. Pond mean concentration of total phosphorous. Overall mean total phosphorous (TP) concentrations varied between ponds sampled in this study. Standard error bars are shown. There is variation in concentration throughout the ponds (Table 1, Appendix B). 


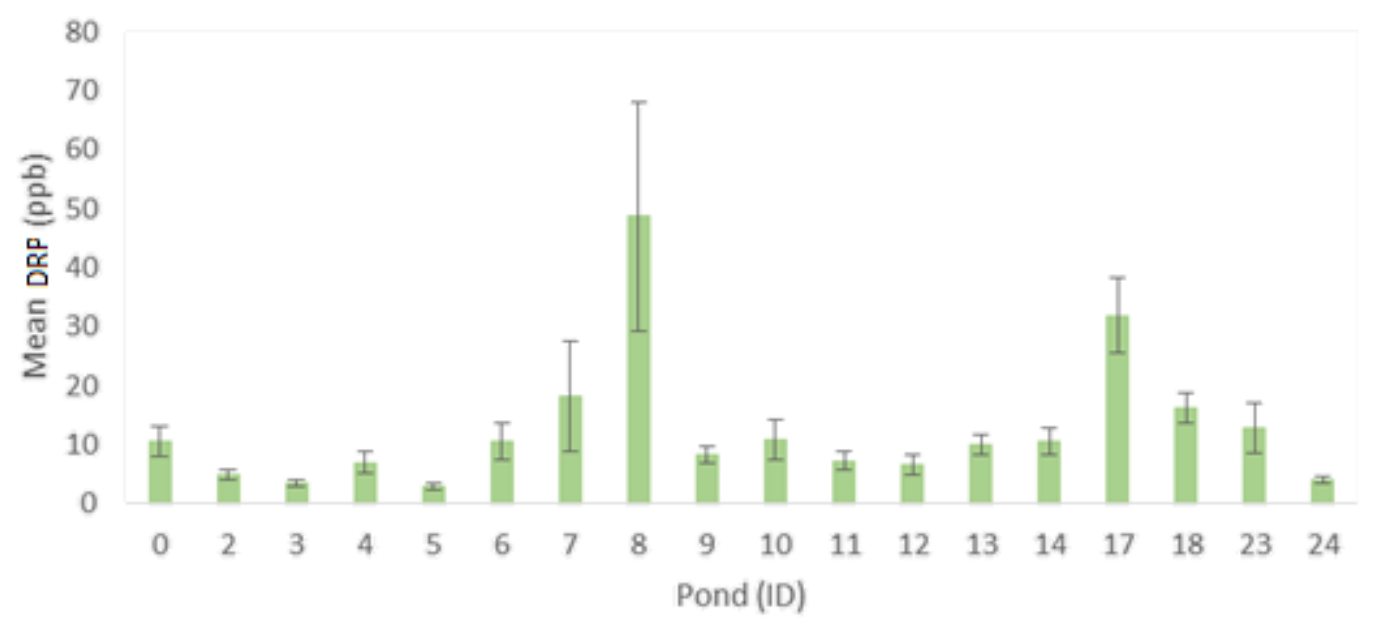

Figure 4. Pond mean concentration of dissolved reactive phosphorous. Overall mean DRP concentrations for each pond and error bars are shown. Standard error bars are shown. There is variation in concentration throughout the ponds (Table 1, Appendix B) attributes.

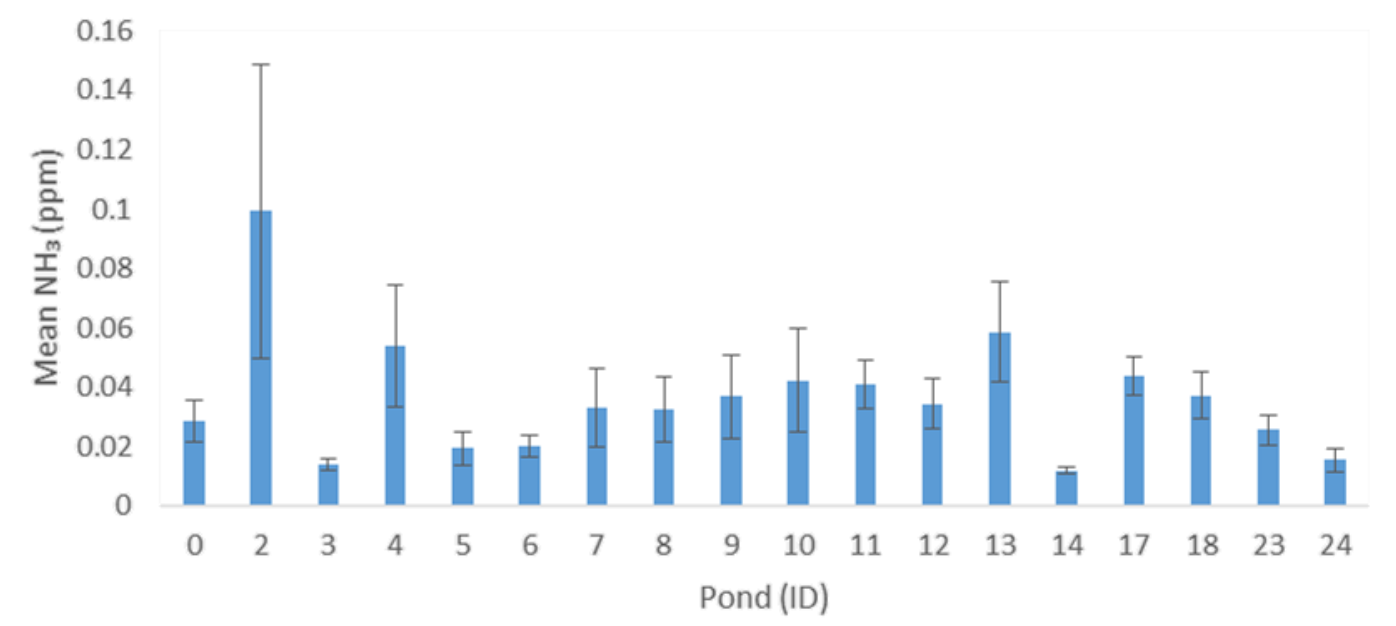

Figure 5. Pond mean concentration of ammonia. Overall mean $\mathrm{NH}_{3}$ concentrations for each pond and error bars are shown. Standard error bars are shown. There is variation in concentration throughout the ponds (Table 1, Appendix B) attributes. 


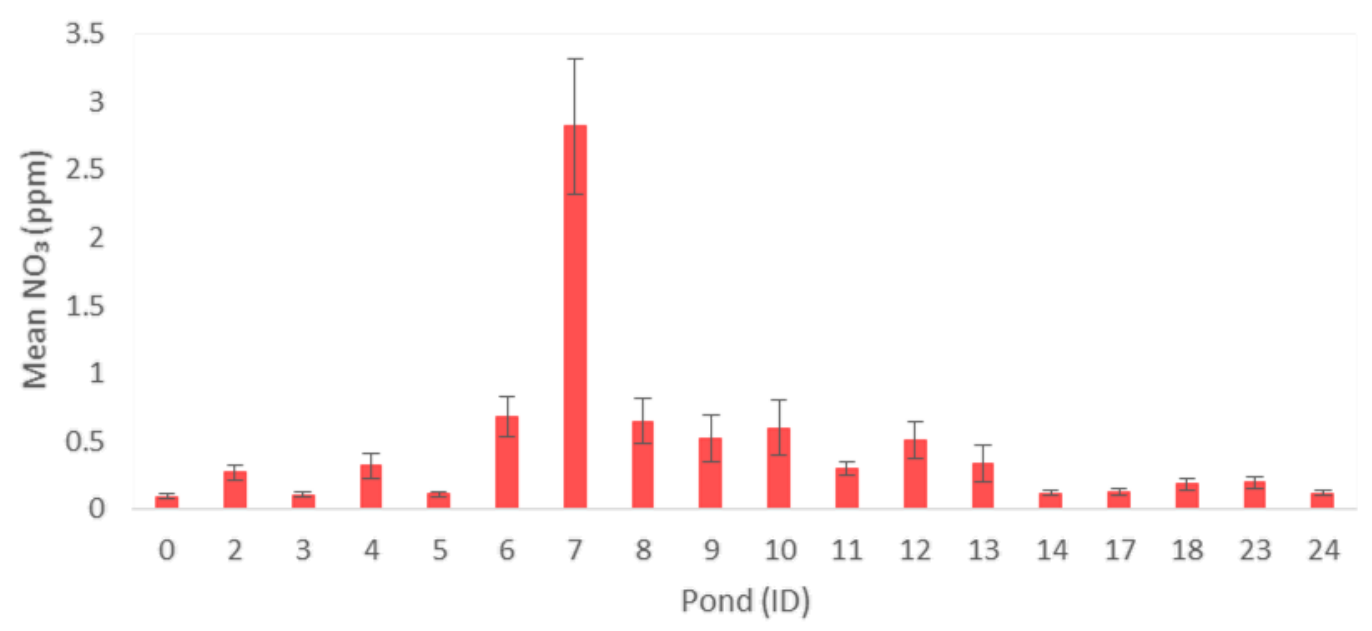

Figure 6. Pond mean concentration of nitrate. Overall mean $\mathrm{NO}_{3}$ concentrations for each pond and error bars are shown. Standard error bars are shown. There is variation in concentration throughout the ponds (Table 1, Appendix B) attributes.

\section{Pre and Post Storm Comparison and Nutrients}

This study included one storm sampling date 3 days after a typical biweekly sampling date that occurred on June 6th. When comparing these two sampling dates, we found a significant difference between the pre-storm and post-storm $\mathrm{TP}$ and $\mathrm{NH}_{3}$ concentrations (Figure 7, 8). Analyses using precipitation data for all sampling dates were not conducted since the relevant data were not able to be normalized and indicated rainfall every day. 


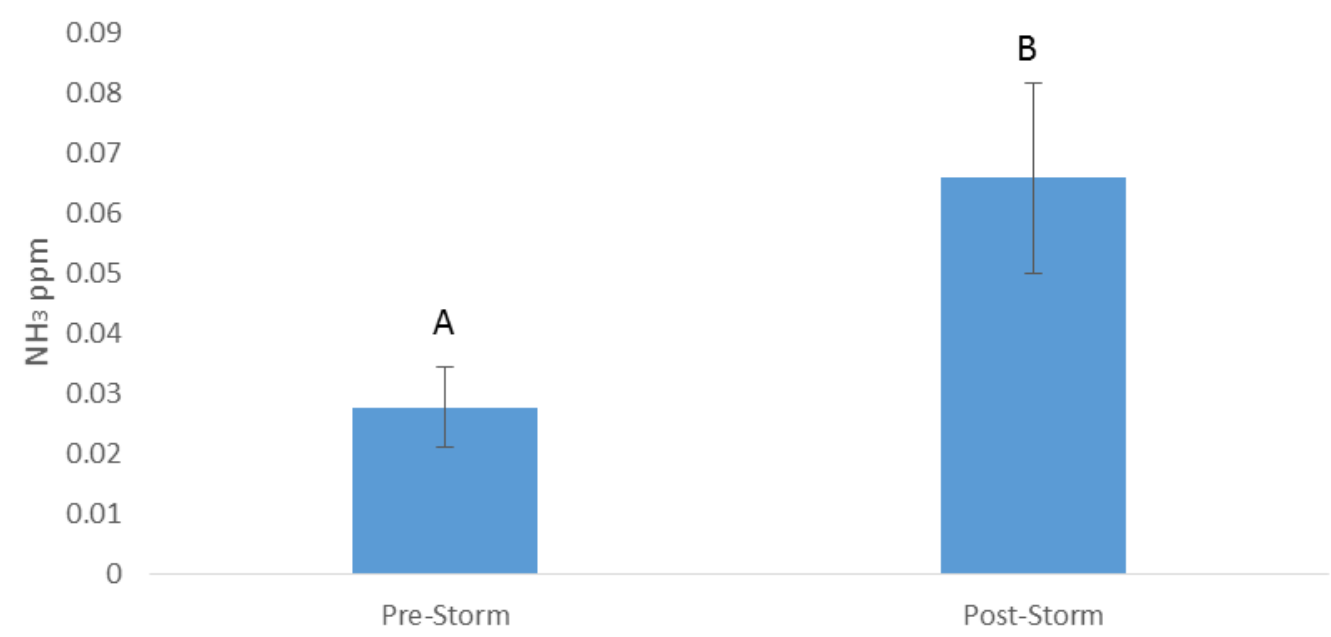

Figure 7. Pre and post storm ammonia concentrations. Ponds on average had significantly more ammonia $\left(\mathrm{NH}_{3}\right)$ in the water after a storm event occurred. An ANOVA was used to determine the relationship. Standard error bars are shown.

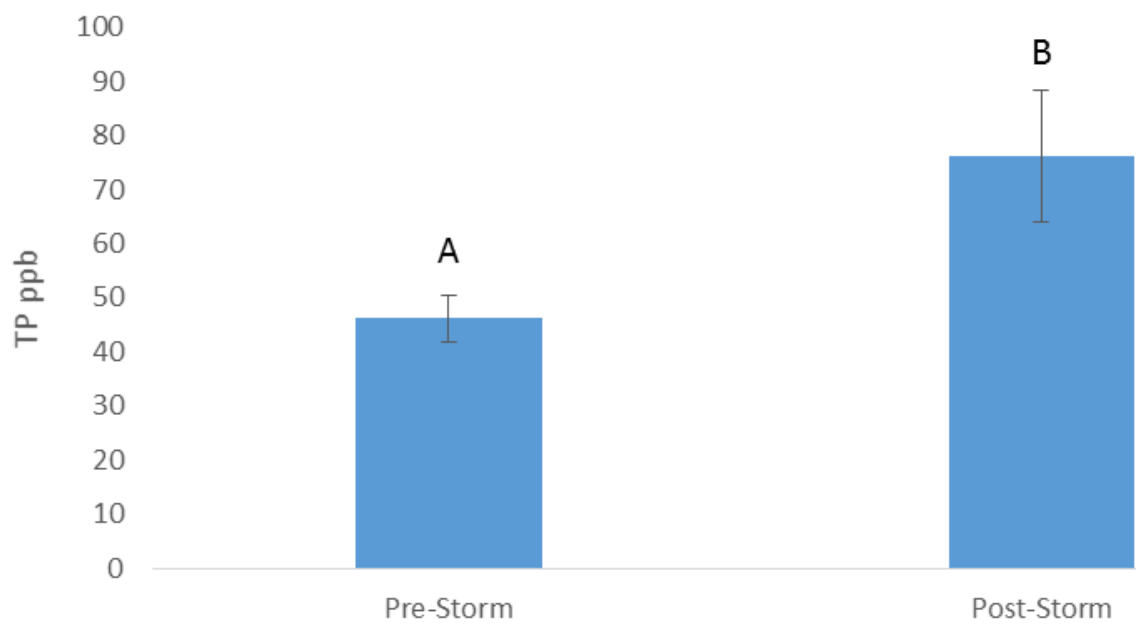

Figure 8. Pre and post storm total phosphorous concentrations. Ponds on average had significantly higher concentrations of total phosphorous (TP) after this storm event occurred. An ANOVA ( $n=18)$ was used to determine the relationship. 


\section{CHAPTER IV: DISCUSSION}

Stormwater ponds in Bloomington, IL exhibited a range and variation of water quality that was not necessarily attributed to dominant land use or land use characteristics. It is not uncommon for ponds to exhibit high variability in water quality measurements including nutrient concentrations and algal community composition (Vincent and Kirkwood 2014). Within our ponds, we saw variation in nutrients from 25-175ppb TP, 2-48ppb DRP, 0.01-0.10 ppm NH 3 , and 0.09-2.82 ppm $\mathrm{NO}_{3}$. TP levels ranged from moderately eutrophic to hypereutrophic (Yang et al. 2008) however, nitrate levels are well below National Primary Drinking Water Regulation (U.S. EPA 2016) Although some ponds contained more nutrients than others; ponds grouped by dominant land uses such as residential, commercial, and golf course were not significantly different from each other. Land use classification by zoning has not been successful in previous attempts to explain water quality and nutrient concentrations in urban ponds (U.S. EPA 1983, U.S. EPA 1999). However, zoning classification has been a successful predictor of the amount of nitrate leaving the system through storm sewers directly (O’Hare 2015). In streams, more specific measurements of land use, such as imperviousness, may show a positive relationship to increases in nutrients and chlorophyll-a (Hatt et al. 2004, Busse et al. 2006, Hoellein et al. 2011). Given that water, which has been affected by land use, may enter streams or sewers that enter ponds, land use may have an indirect effect on water quality in stormwater ponds.

Stormwater ponds showed relatively little correlation between land use characteristics and nutrients especially when considering the large gradient of specific watershed attributes observed among ponds. This was surprising since it is known that measures of urbanization, such as impervious surface cover, are correlated to surface water degradation within streams (Hatt et al. 2004, Busse et al. 2006, Hoellein et al. 2011). No relationship was found between land use 
characteristics and nutrient concentrations in these ponds. The only statistically significant relationship of land use on nutrients within ponds was a negative relationship between pondshed area and ammonia concentration in spring. This relationship may be due to the uptake of ammonia by plants in the pondshed before surface runoff was deposited into the pond. Terrestrial plants will use both nitrate and ammonia from the soil; however, the preferred nitrogen source is determined by soil conditions (Xu-ri and Prentice 2008). Another possible explanation for the relationship between pondshed area and ammonia concentration may be found within the pond itself. Ammonia removal rates within ponds may be affected by the ratio of stormwater pond area to watershed area (Koch et al. 2014). Stormwater ponds are specifically designed to increase residence time of water to slow the release downstream (Trixier et al. 2001, Walsh et al. 2005). Increased residence time may be causing an increased biotic effect on nutrient concentrations within the pond by increasing the opportunity for nutrient uptake (Herrmann 2012).

Green algal richness increased with some measures of urbanization including watershed area, sewershed area, and pipe length. Green algae are known to increase in richness with a decrease in nutrient concentrations within suburban streams (Paril et al. 2010). The relationship between green algae and urbanization in this study suggests that the urban land use we measured may not play as large of a role as lawn area might. In all our stormwater ponds, it seemed that most areas that were not impervious were lawns, therefore suggesting a stronger effect of land management strategies and fertilizer applications than that of urbanization in general. In urban landscapes, fertilizers from lawns alter nutrient concentrations in receiving water bodies (U.S. EPA 2016). Golf courses may contribute to surface water degradation due to fertilizer inputs (Shuman 2002, Rice and Horgan 2011) that increase phosphorous levels in ponds significantly, resulting in eutrophication and increased algal growth (Rice and Horgan 2011). Golf course 
ponds in this study include ponds 17,18 , and 23 . The mean TP concentration in our golf course ponds was around 100ppb or greater, indicating eutrophic to hypereutrophic levels of TP (Yang et al. 2008). Timing of fertilizer applications on lawns may be the most important fertilizer variable to consider (Bachman et al. 2016). Attention to fertilizer application and land management practices could aid in determining if fertilizer application is related to algal richness and biomass within our study sites however, residence time of water in ponds should not be ignored.

Algal richness was expected to correlate not only with urban characteristics, but with nutrients as well. There was not much pattern between land use and nutrients in our ponds and therefore the dynamic in richness seems more complicated than it first appeared. Typically, an increase in taxon richness may be attributed to oligotrophic conditions and it has been shown that algal richness may respond to gradients of nutrients in eutrophic water bodies in this fashion (Paril et al. 2010). Cyanobacterial richness decreased with an increase in the number of inlets while diatom richness decreased with an increase in percent imperviousness. It is unclear whether the relationship we observed between richness and urbanization is characteristic of stormwater ponds. Diatom communities may shift from low-nutrient diatoms to motile highnutrient diatoms at impervious surface thresholds as low as 0.7 and $4.5 \%$ imperviousness (Smucker et al. 2013). Diatom genera observed in our ponds were typical of diverse water conditions including mesotrophic water, eutrophic water, nutrient deficient water, and polluted water (Palmer 1969, Reynolds et al. 2002). Cyanobacterial genera observed were pollutant tolerant genera that are typical of low carbon, nitrogen, and eutrophic systems (Palmer 1969, Reynolds et al. 2002). 
Cyanobacteria did not dominate our ponds in the same way they did in many studies. In Ontario, Canada 22 stormwater ponds and 3 reference ponds had Microcystis in their ponds and Microcystis was dominant in most of those stormwater ponds as well (Vincent and Kirkwood 2014). In our study, Microcystis was only observed twice, one of those times during an algae bloom. Only one pond (Pond 10) experienced a cyanobacterial bloom; it occurred on September $24^{\text {th }}, 2015$. Pond 10 is nestled within a residential area that also receives water from a second pond (Pond 9). Further 'upstream' of these ponds, a sewer burst at the beginning of spring and may have influenced the nutrient and algae cycling of the pond this season. Pond 9 and 10 also received algaecide treatments in spring and fall of 2015 . The bloom in pond 10 was typical in the sense that it was dominantly Microcystis, Anabaena, and Aphanizomenon. Each dominant cyanobacterium observed during that bloom has the potential to form toxins that may be harmful to human and animal health (Oriheil et al. 2013). The cyanobacteria present within the pond at this time indicate the waters may be low in nitrogen and carbon (Reynolds et al. 2002). The phosphorous levels in pond 10 during the bloom was $78 \mathrm{ppb}$, indicating eutrophic conditions (Paril et al. 2010, Vincent and Kirkwood 2014). The ammonia level was 0.01ppm and the nitrate was below detection limits. These nutrient levels indicate potential nitrogen depletion within the pond resulting in an N:P that may favor a cyanobacterial bloom (Stancheva et al. 2013). Bloomington may have less Microcystis present in ponds than other studies have reported (Vincent and Kirkwood 2014), and future research should work toward determining whether our ponds are different and if so, why that may be.

Overall, our stormwater ponds in Bloomington, IL exhibited complicated patterns in water quality and algal community dynamics when considering urban land use characteristics. The lack of relationship between land use and nutrient concentration in ponds likely does not 
indicate that land use had no effect on water quality; rather it likely shows that interactions within the biotic community are having an influence on the data collected. Biotic interactions could shed light on important ecological mechanisms occurring in surface waters in stormwater ponds. Future research should focus on such ecological mechanisms and on land management practices concerning fertilizer application. Further observations of algal dynamics in these systems may be helpful toward determining land use connections that influence algal blooms and may influence urban planning efforts. Surface water pollution and degradation is an issue worldwide that is affected by urbanization. Attention toward stormwater ponds may help improve community health by minimizing harmful algal blooms and increasing the health of water used for drinking and recreation. Urban stormwater ponds in this study had variable concentrations of nutrients that did not always indicate poor water quality. Stormwater ponds may be effective in nutrient removal prior to the release of water downstream and may allow urban areas to have a less negative ecological effect on receiving waters. Understanding stormwater ponds will be instrumental toward improving and maintaining the health of surface waters. 


\section{REFERENCES}

Bachman, M., Inamdar, S., Barton, S., Duke, J.M., Tallamy, D., Bruck, J., A comparative assessment of runoff nitrogen from turf, forest, meadow, and mixed landuse watersheds. Journal of the American Water Resources Association 52(2), 397-408 (2016).

Bernhardt, E.S. and Palmer, M.A., Restoring streams in an urbanizing world. Freshwater Biology 52, 738-751 (2007).

Bernhardt, E.S., Band, L.E., Walsh, C.J., Berke, P.E., Understanding, managing, and minimizing urban impacts on surface water nitrogen loading. Annals of the New York Academy of Sciences 1134, 61-96 (2008).

Borden, R.C., Dorn, J.L., Stillman, J.B., Liehr, S.K., Evaluation of wet ponds for protection of public water supplies. Department of Civil Engineering. 50184 (1997).

Brezonik, P.L. et al., Effects of reducing nutrient loads to surface waters within the Mississippi River Basin and the Gulf of Mexico. NOAA Coastal Ocean Program. 18 (1999).

Brown, G.W. and Krygier, J.T., Effects of clear-cutting on stream temperature. Water Resources Research 6(4), 1133-1139 (1970).

Busse, L.B., Simpson, J.C., Cooper, S.D., Relationships among nutrients, algae, and land use in urbanized southern California streams. Can. J. Fish. Aquat. Sci 63, 2621-2638 (2006).

Carey, C.C., Ibelings, B.W., Hoffmann, E.P., Hamilton, D.P., Brookes, J.D., Eco-physiological adaptations the favour freshwater cyanobacteria in a changing climate. Water Research 46, 1394-1407 (2012).

Carr, G.M., Chambers, P.A., Morin, A., Periphyton water quality, and land use at multiple spatial scales in Alberta rivers. Can. J. Fish. Aquat. Sci. 62, 1309-1319 (2005). 
Childress, E.S., Papke, R., and McIntyre, P.B., Spawning success and early life history of longnose suckers in the Great Lakes tributaries. Ecology of Freshwater Fish. 25(3), 393404 (2016).

Dietz, M.E., Low impact development practices: a review of current research and recommendations for future directions. Water, Air, and Soil Pollution 186, 351-363 (2007).

Drerup, S.A., and Vadeboncoeur, Y., Elevated specific conductance enhances productivity and biomass of periphytic cyanobacteria from Lake Tahoe and Lake Tanganyika. Phycologia. 55(3), 295-298 (2016).

Ekvall, M.K., Martin, J.D., Faassen, E.J., Gustafsson, S., Lürling, M., Hansson, L., Synergistic and species-specific effects of climate change and water colour on cyanobacterial toxicity and bloom formation. Freshwater Biology. 58, 2414-2422 (2013).

Fitzgerald, E.P., Bowden, W.B., Parker, S.P., Kline, M.L., Urban impacts on streams are scaledependent with nonlinear influences on their physical and biotic recovery in Vermont, United States. Journal of the American Water Resources Association. 48(4), 679-697 (2012).

Graham, J.E., Wilcox, L.W., Graham, L.E., Algae $2^{\text {nd }}$ edition. Benjamin Cummings Text (2009). Greenway, M., Stormwater treatment trains in subtropical Australia- wetland and pond systems: how effective are they in improving water quality and enhancing ecosystem biodiversity. SIA Queensland State Conference 1-16 (2005).

Hatt, B.E., Fletcher, T.D., Walsh, C.J., Taylor, S.L., The influence of urban density and drainage infrastructure on the concentrations and loads of pollutants in small streams. Environmental Management 34(1), 112-124 (2004). 
Herrmann, J., Chemical and biological benefits in a stormwater wetland in Kalmar, SE Sweden. Limnologica 42(4), 299-309 (2012).

Hester, E.T. and Bauman, K.S., Stream and retention pond thermal response to heated summer runoff from urban impervious surfaces. Journal of the American Water Resources Association. 49(2), 328-342 (2013).

Hoellein, T.J., Arango, C.P., Zak, Y., Spatial variability in nutrient concentration and biofilm nutrient limitation in an urban watershed. Biogeochemistry. 106, 265-280 (2011).

Hogan, D.M. and Walbridge, M.R., Best management practices for nutrient and sediment retention in urban stormwater runoff. J. Environ. Qual. 36, 386-395 (2007).

Hollis, G. E., The effect of urbanization on floods of different recurrence interval. Urban Hydrogeography 11(3), 431-435 (1975).

Johnson, K.A., Steinman, A.D., Keiper, W.D., Ruetz, C.R., Biotic responses to lowconcentration urban road runoff. J. N. Am. Benthol. Soc. 30(3), 710-727 (2011).

Klose, K., Cooper, S.D., Leydecker, A.D., Kreitler, J., Relationships among catchment land use and concentrations of nutrients, algae, and dissolved oxygen in a southern California river. Freshwater Science 31(3), 908-927 (2012).

Koch, B.J., Febria, C.M., Geurey, M., Wainger, L.A., Palmer, M.A., Nitrogen removal by stormwater management structures: a data synthesis. Journal of the American Water Resources Association 50(6), 1594-1607 (2014).

Lewitus, A.J. et al., Harmful algal blooms in South Carolina residential and golf course ponds. Population and Environment 24(5), 387-413 (2003). 
Likens, G.E., Bormann, F.H., Johnson, N.M., Fisher, D.W., Pierce, R.S., Effects of forest cutting and herbicide treatment on nutrient budgets in the Hubbard Brook watershed-ecosystem. Ecological Monographs 40(1), 23-47 (1969).

Mallin, M.A., Ensign, S.H., Wheeler, T.L., Mayes, D.B., Surface water quality: pollutant removal efficacy of three wet detention ponds. J. Environ. Qual. 31,654-660 (2002).

Michalak, A.M. et al., Record-setting algal bloom in Lake Erie caused by agricultural and meteorological trends consistent with expected future conditions. PNAS 110(16), 6448$6452(2013)$.

Mitsch, W.J., Day, J.W., Filliam, J.W., Groffman, P.M., Hey, D.L., Randall, G.W., Wang, N., Reducing nitrogen loading to the Gulf of Mexico from the Mississippi river basin: strategies to counter a persistent ecological problem. BioScience 51(5), 373-388 (2001).

O'Hare, A.T., Effects of physical characteristics of urban storm sewersheds on the water quality in Bloomington, IL. MS Thesis (2015).

O’Farrell, I., Bordet, F., Chaparro, G., Bloom forming cyanobacterial complexes co-occurring in a subtropical large reservoir: validation of dominant eco-strategies. Hydrobiologia 698,175-190 (2012).

Olofsson, J. and Hickler, T., Effects of human land-use on the global carbon cycle during the last 6,000 years. T. Veget, Hist. Archaeobot. 17(5), 605-615 (2008).

Orihel, D.M., Hadas, O., Pinkas, R., Viner-Mozzini, Y., Sukenik, A., Internal nutrient loading may increase microcystin concentrations in freshwater lakes by promoting growth of Microcystis populations. Ann. Limnol. 49, 225-235 (2013).

Palmer, C.M., A composite rating of algae tolerating organic pollution. J. Phycol. 5, 78-82 (1969). 
Paril, P., Sukavova, K., Syrovatka, V., Mala, J., Kralova, H., The effect of environmental parameters on algal assemblages in human-impacted suburban brooks. Fresenius Environmental Bulletin 19(12a), 2947-2957 (2010).

Paul, M.J., Meyer, J.L., Streams in the urban landscape. Annu. Rev. Ecol. Syst. 32, 333-365 (2001).

Pennino, M.J., Kaushal, S.S., Beaulieu, J.J., Mayer, P.M., Arango, C.P., Effects of urban stream burial on nitrogen uptake and ecosystem metabolism: implications for watershed nitrogen and carbon fluxes. Biogeochemistry 121, 247-269 (2014).

Prescott, G.W., How to know the freshwater algae 3rd edition. McGraw-Hill College. (1978).

Ramankutty, N., Foley, J.A., Estimating historical changes in global land cover: croplands from 1700 to 1992. Glob. Biogeochem. Cycles 13(4), 997-1027 (1999).

Reynolds, C.S., Huszar, V., Kruk, C., Naselli-Flores, L., Melo, S., Towards a functional classification of the freshwater phytoplankton. Journal of Plankton Research 24(5), 417428 (2002).

Rice, P.J. and Horgan, B.P., Nutrient loss with runoff from fairway turf: an evaluation of core cultivation practices and their environmental impact. Environmental Toxicology and Chemistry 30(11), 2473-2480 (2011).

Rockstrom, J., Steffen, W.L., Noone, K., Persson, A., Chapin, F.S., Planetary boundaries: exploring the safe operating space for humanity. Ecology and Society 14(2), 32 (2009).

Shuman, L.M., Phosphorous and nitrogen in runoff following fertilizer application to turfgrass. $J$. Environ. Qual. 31, 1710-1715 (2002). 
Smucker, N.J, Detenbeck, N.E., Morrison A.C., Diatom responses to watershed development and potential moderating effects of near-stream forest and wetland cover. Freshwater Science 321, 230-249 (2013).

Stancheva, R., Sheath, R.G., Read, B.A., McArthur, K.D., Schroepfer, C., Kociolek, J.P., Fetscher, A.E., Nitrogen-fixing cyanobacteria (free-living and diatom endosymbionts): their use in southern California stream bioassessment. Hydrobiologia 720, 111-127 (2013).

Stearman, L.W., Lynch, D.T., Patterns of assemblage change in prairie stream fishes in relation to urban stormwater impoundments. Hydrobiologia 718, 221-235 (2013).

Steffen, W. et al., Planetary boundaries: guiding human development on a changing planet. Science express 32, 1-16 (2015).

Stevenson, R.J., Bennett, B.J., Jordan, D.N., French, R.D., Phosphorous regulates stream injury by filamentous green algae, DO, and ph with thresholds in responses. Hydrobiologia 695, 25-42 (2012).

Strecker, E.W., Quigley, M.M., Urbonas, B.R., Jones, J.E., Clary, J.K., Determining urban storm water bmp effectiveness. Journal of Water Resources Planning and Management 127, 144-149 (2001).

Tribe, A., Automated recognition of valley lines and drainage networks from grid digital elevation models- a review and a new method. Journal of Hydrology 139, 263-293 (1992).

Trixier, G., Rochfort, Q., Grapentine, L., Marsalek, J., Lafont, M., Spatial and seasonal toxicity in a stormwater management facility: evidence obtained by adapting an integrated sediment quality assessment approach. Water Research 46(20), 6671-6682 (2001). 
U.S. EPA, Results of the nationwide urban runoff program: volume 1 - final report. Water Planning Division NTIS 83-185552 (1983).

U.S. EPA, Preliminary data summary of urban storm water best management practices. Office of Water (4303) Washington, DC 20460 EPA-821-R-99-012 (1999).

U.S. EPA, Nutrient pollution sources and solutions: stormwater. US Environmental Protection Agency (2016).

Vincent, J., Kirkwood, A.E., Variability of water quality, metals and phytoplankton community structure in urban stormwater ponds along a vegetation gradient. Urban Ecosyst. 17,839853 (2014).

Walsh, C.J., Roy, A.H., Feminella, J.W., Cottingham, P.D., Groffman, P.M., Morgan, R.P., The urbans stream syndrome: current knowledge and the search for a cure. Journal of the North American Benthological Society 24(3), 706-723 (2005).

Williams, P., Whitfield, M., Biggs, J., Bray, S., Fox, G., Nicolet, P., Sear, D., Comparative biodiversity of rivers, streams, ditches and ponds in an agricultural landscape in southern England. Biological Conservation 115, 329-341 (2003).

Williamson, C.E., Salm, C., Cooke, S.L., Saros, J.E., How do UV radiation, temperature, and zooplankton influence the dynamics of alpine phytoplankton communities. Hydrobiologia 648: 73-81. (2010).

Xu-ri and Prentice, C.J., Terrestrial nitrogen cycle simulation with a dynamic global vegetation model. Global Change Biology 14, 1745-1764 (2008).

Yang, X., Wu, X., He, Z., Mechanisms and assessment of water eutrophication. J. Zhejiang Univ. Sci. 9(3), 197-209 (2008). 
Zamyadi, A., Dorner, S., Ndong, M., Ellis, D., Bolduc, A., Bastien, C., Prevost, M., Low-risk cyanobacterial bloom sources: cell accumulation within full-scale treatment plants. Journal American Water Works Association E651-663 (2013).

Zhu, W., Dillard, N.D., Grimm, N.B., Urban nitrogen biogeochemistry: status and processes in green retention basins. Biogeochemistry 71, 177-196 (2004). 


\section{APPENDIX A: SUPPLEMENTARY MATERIALS}

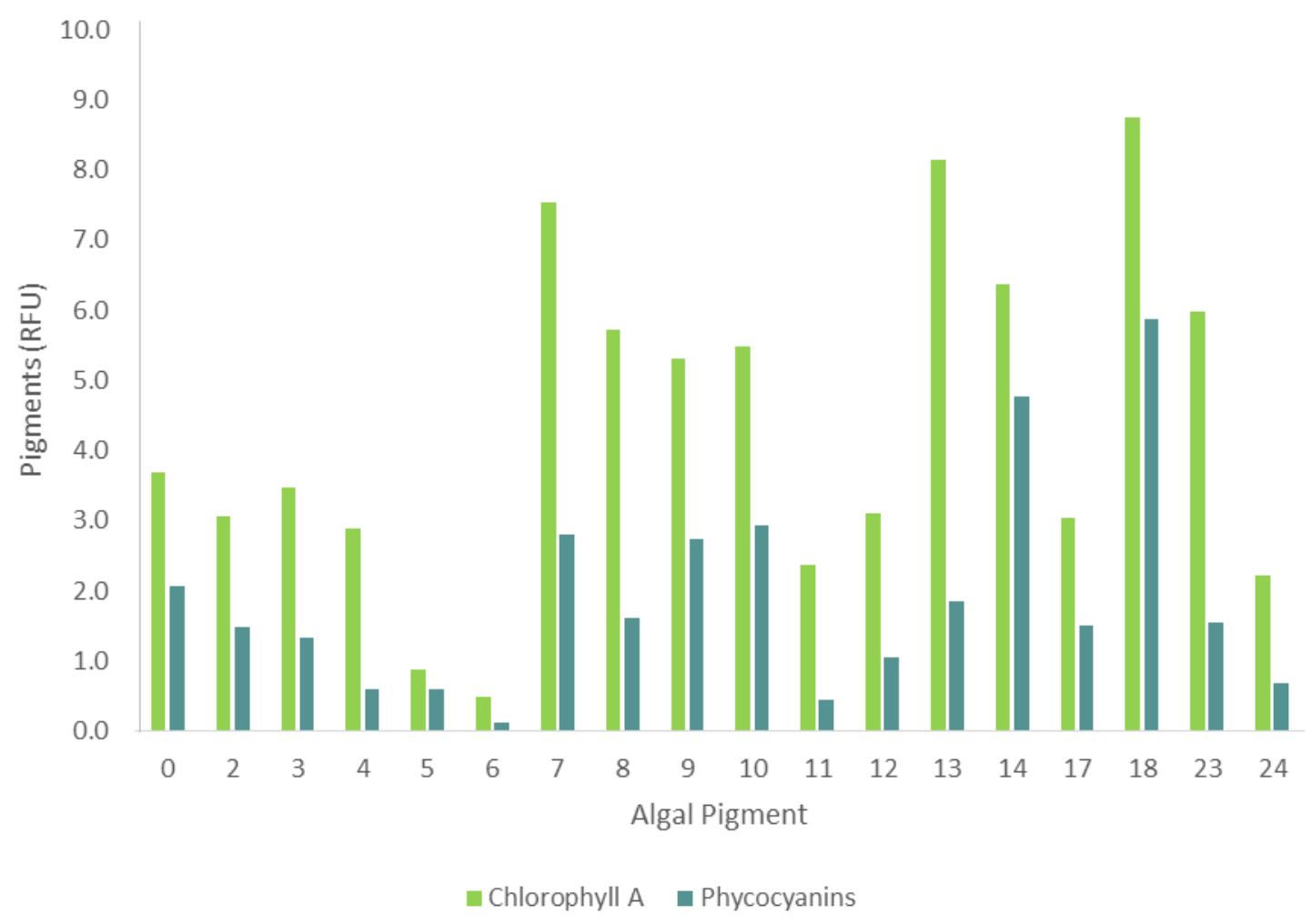

Figure A-1. Algal pigments in 18 stormwater ponds. Mean summer chlorophyll-a and phycocyanin pigments at each pond vary (Table A-3). Other seasons are not shown since pigment data was not taken in any other season except on one other date in spring. 


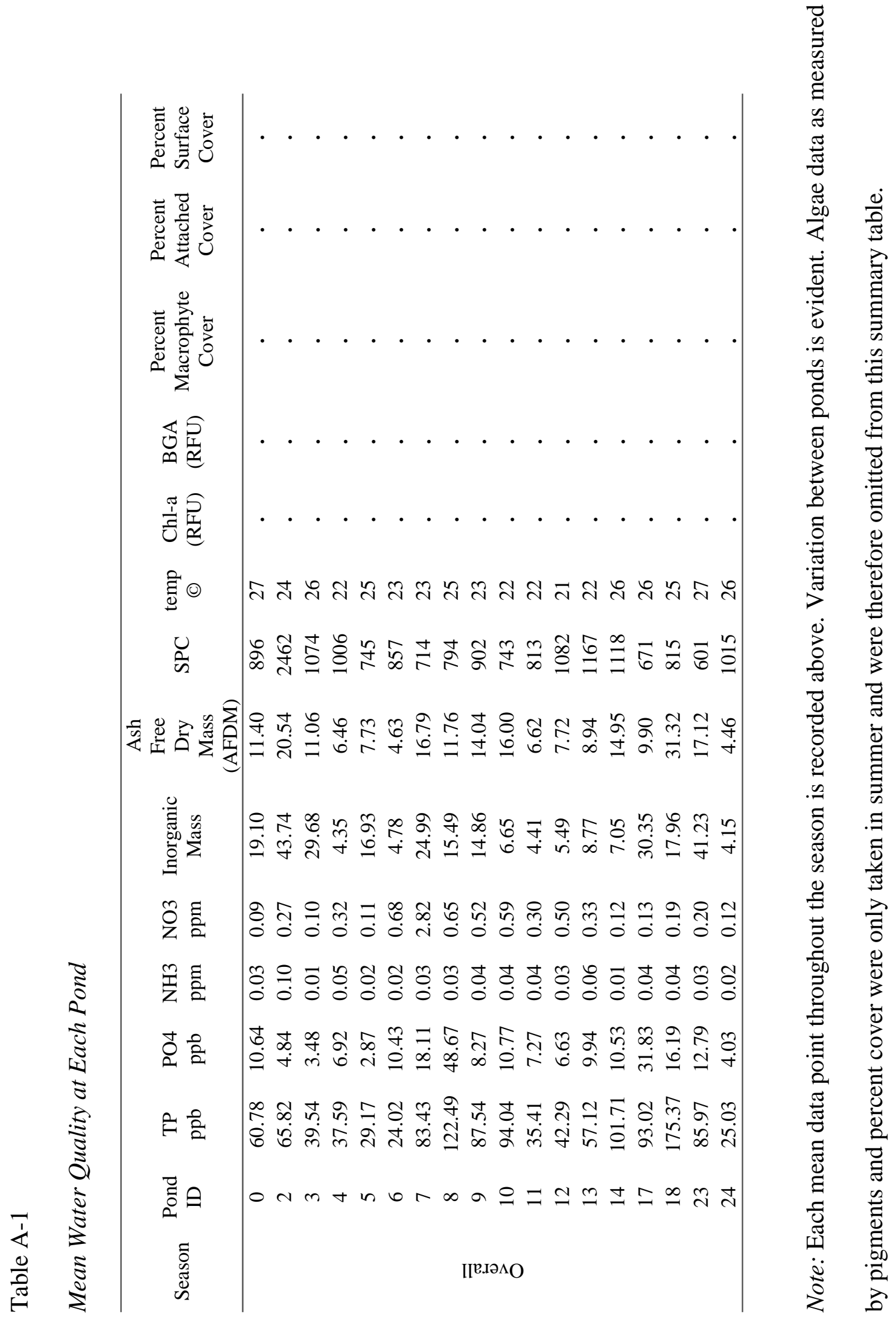




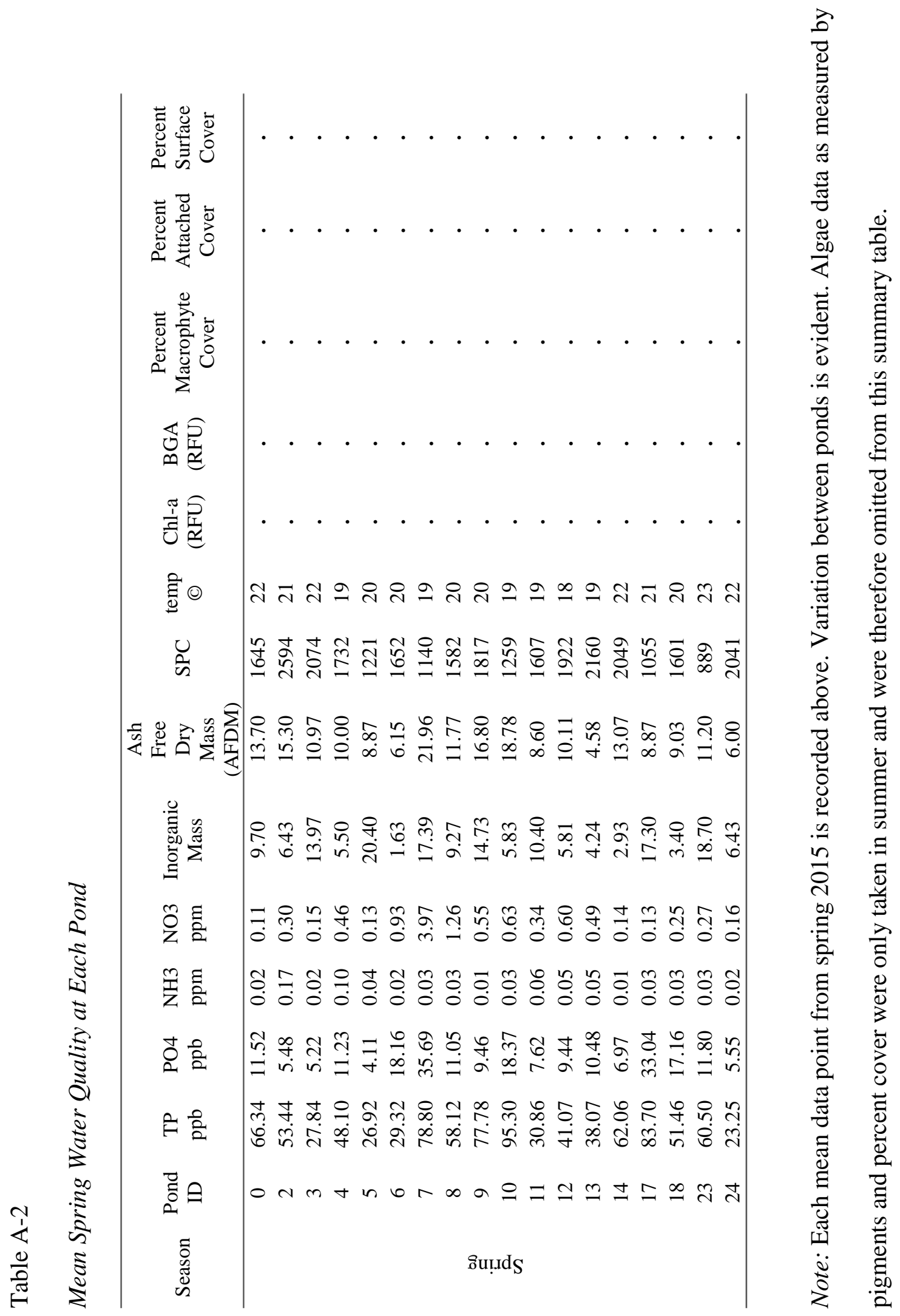




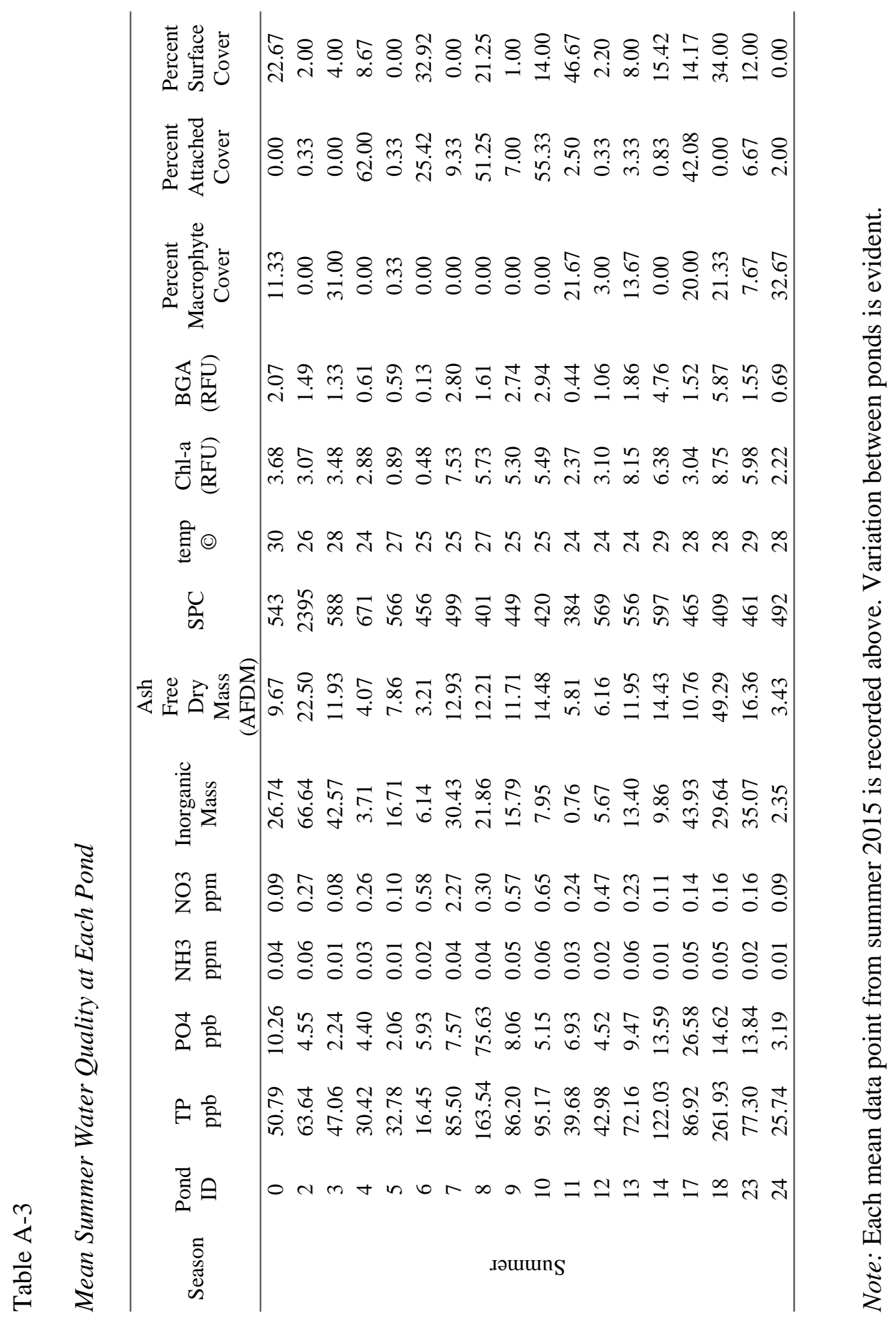




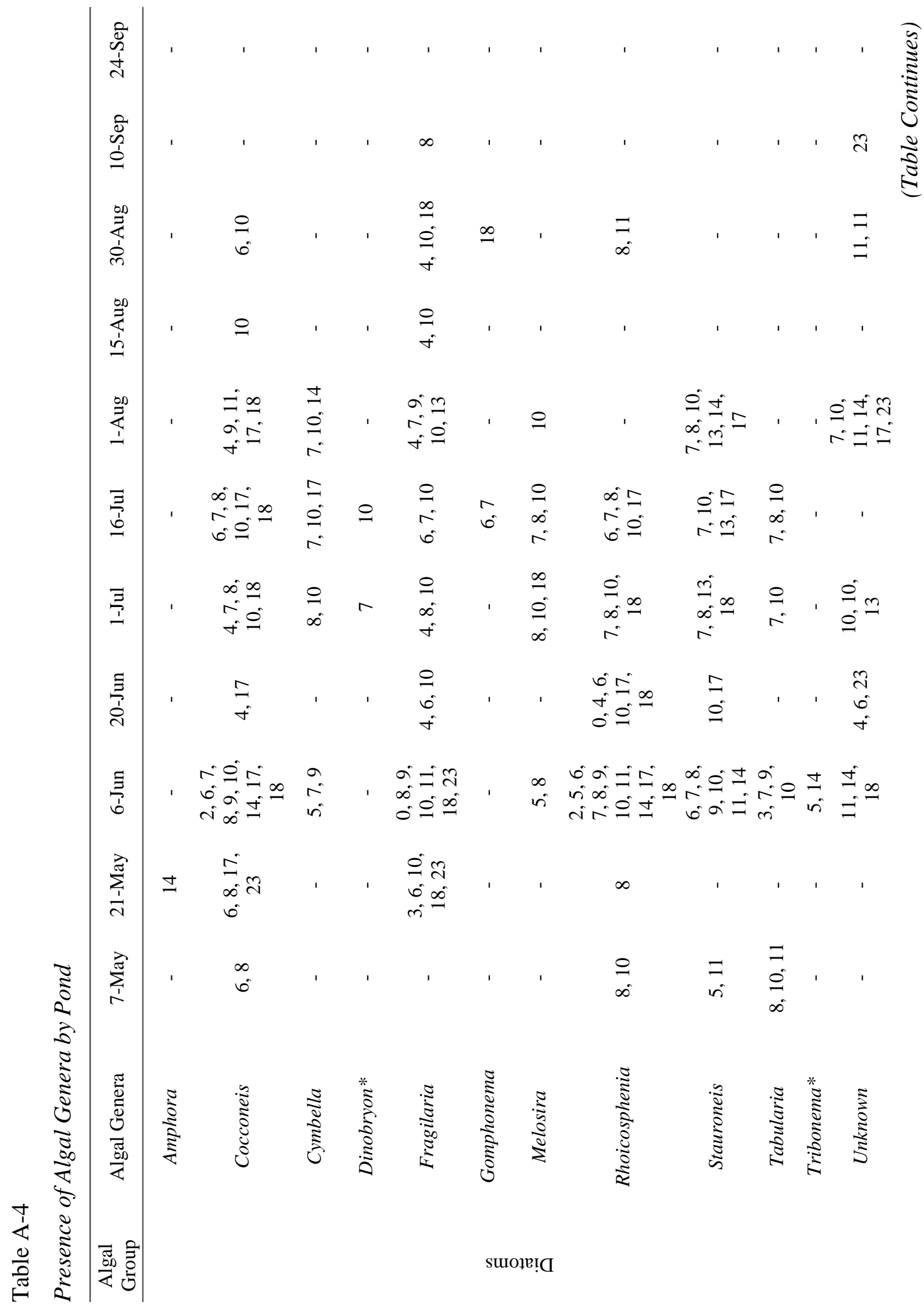




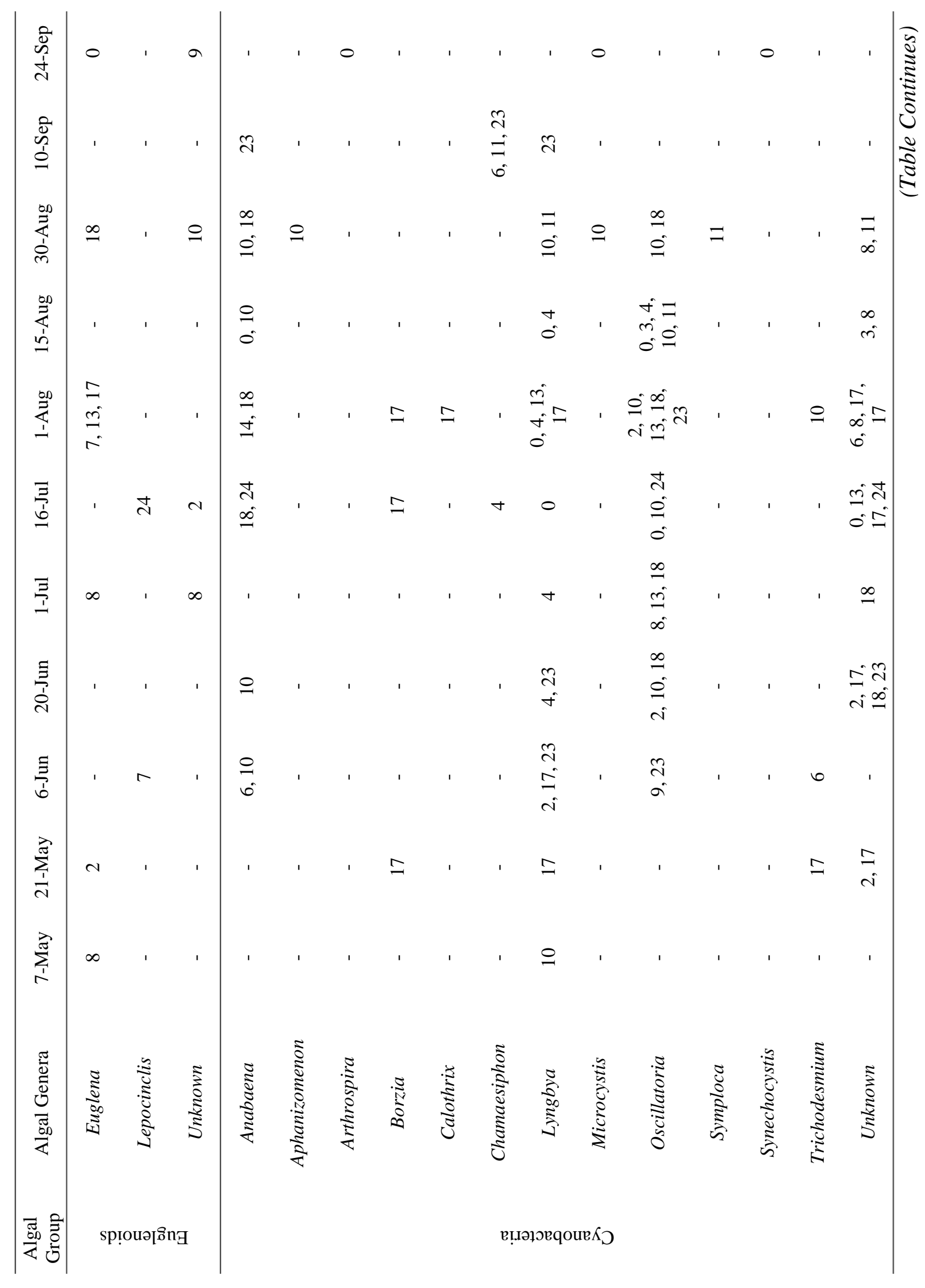




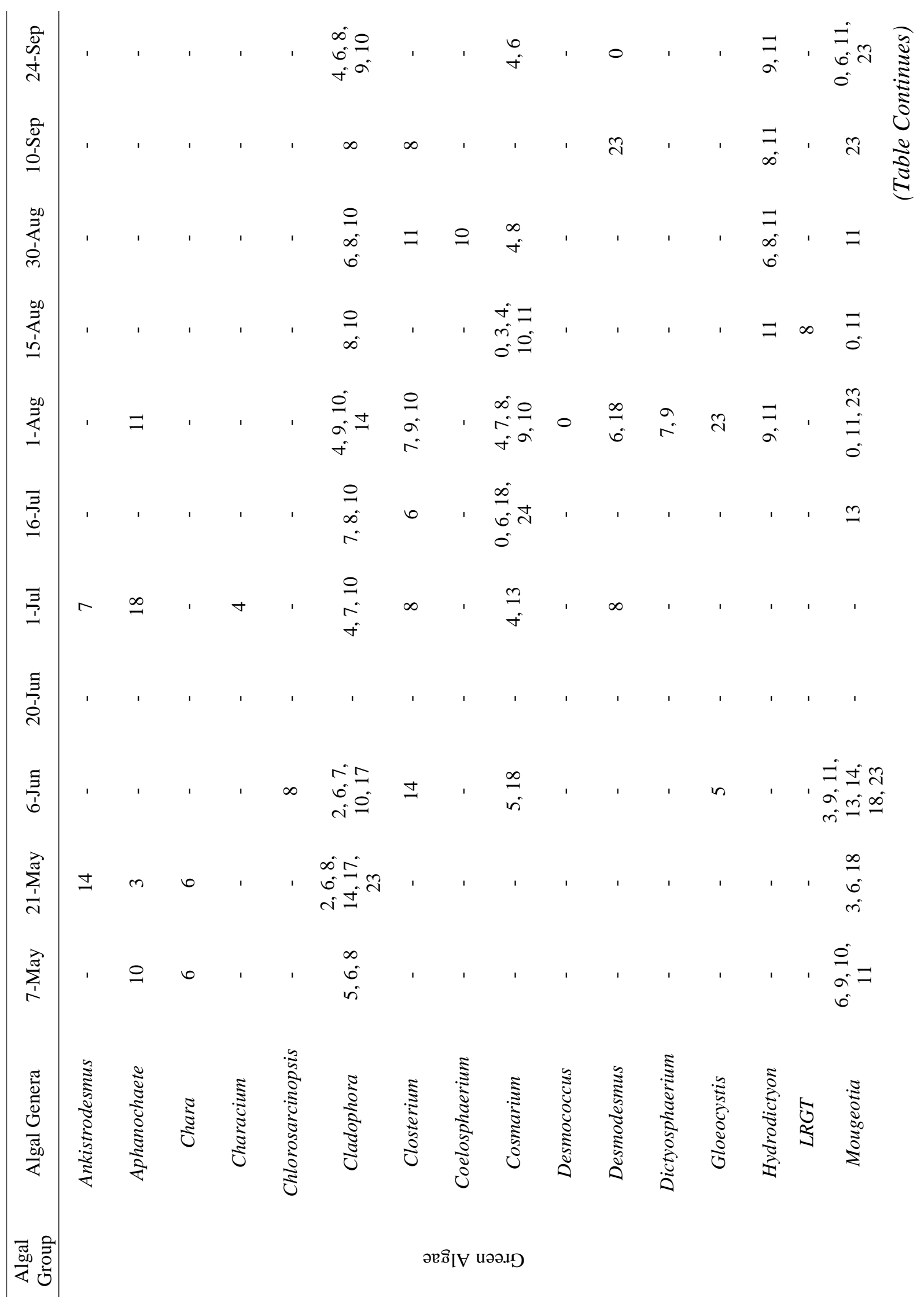




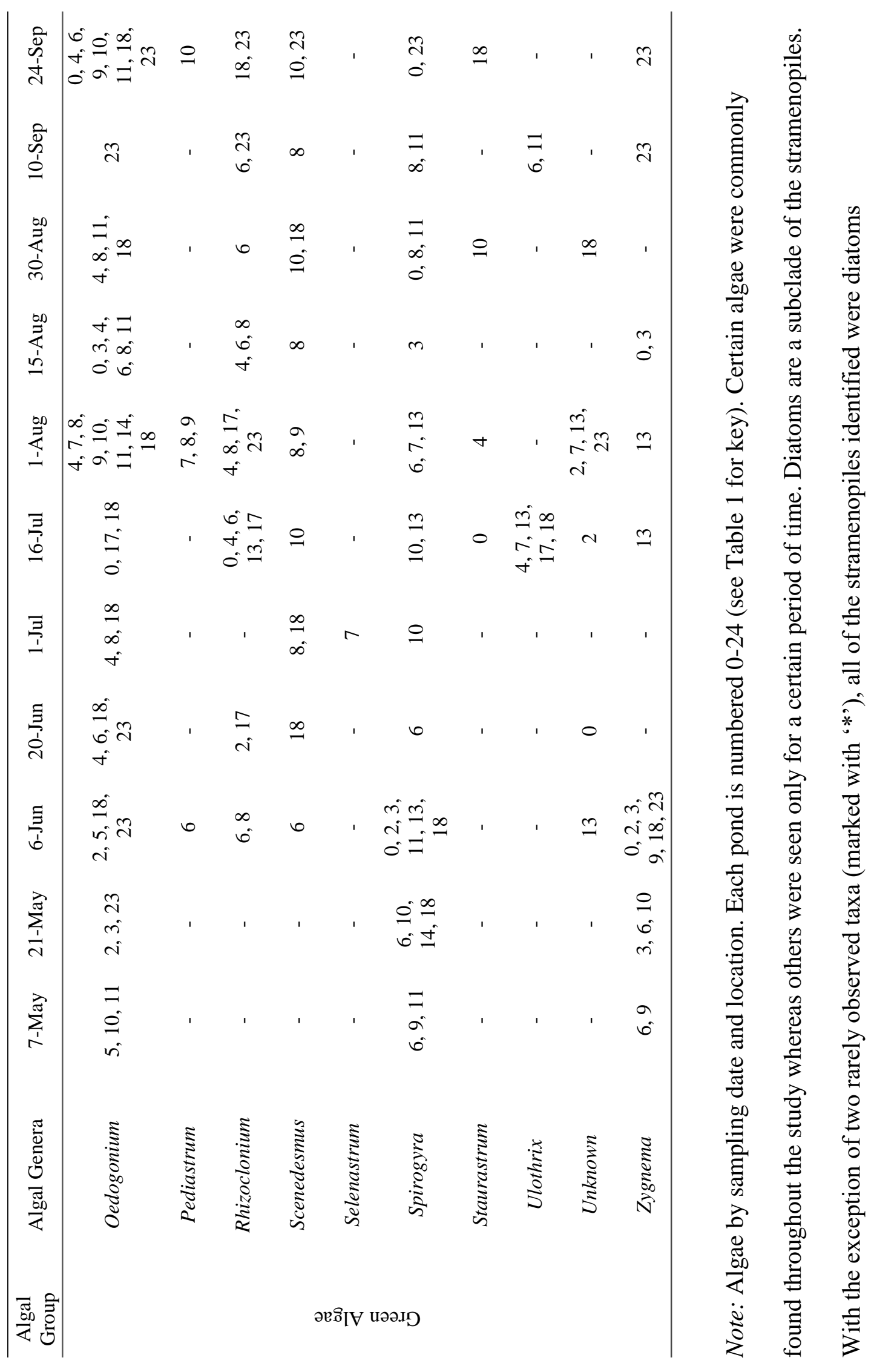




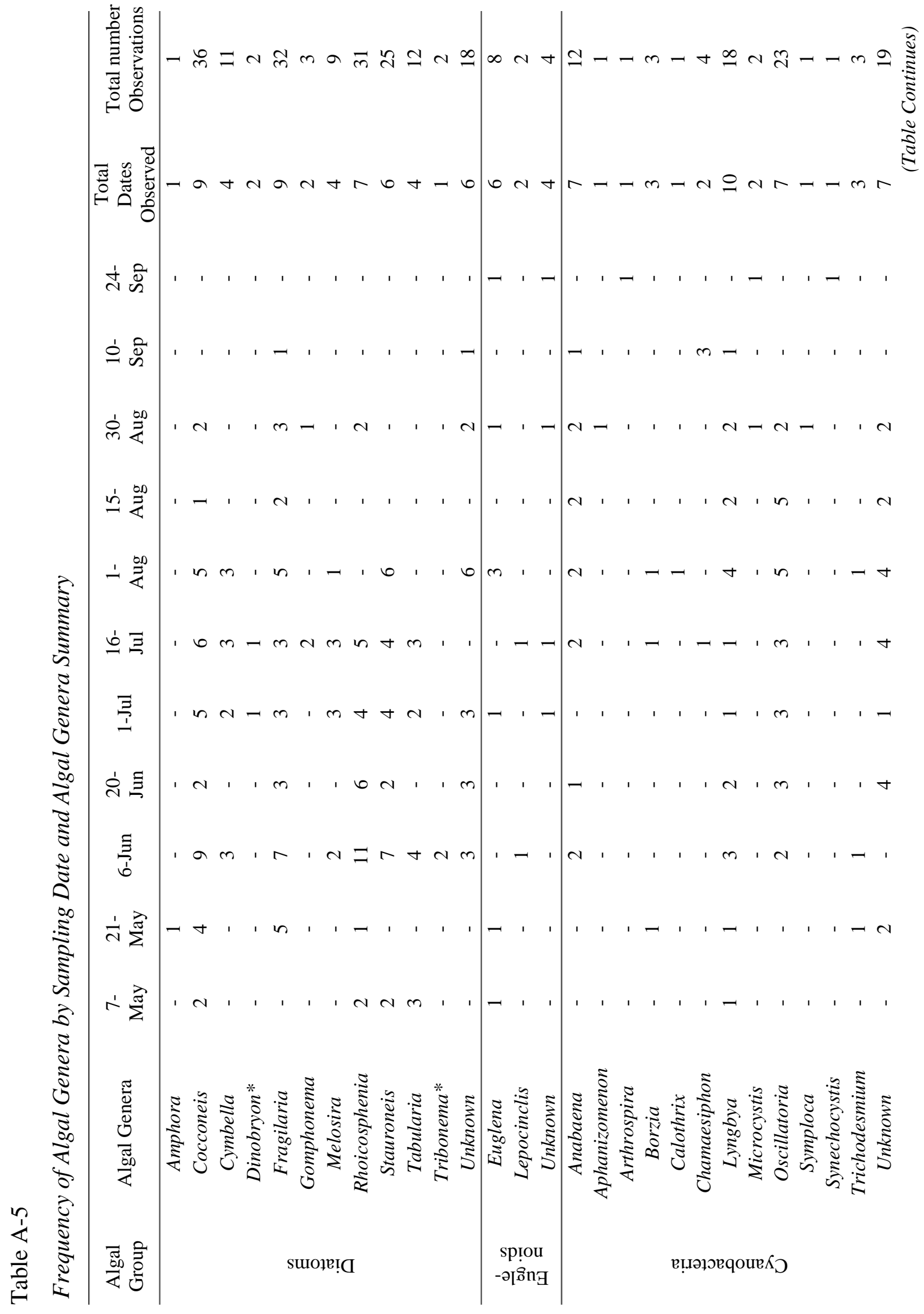




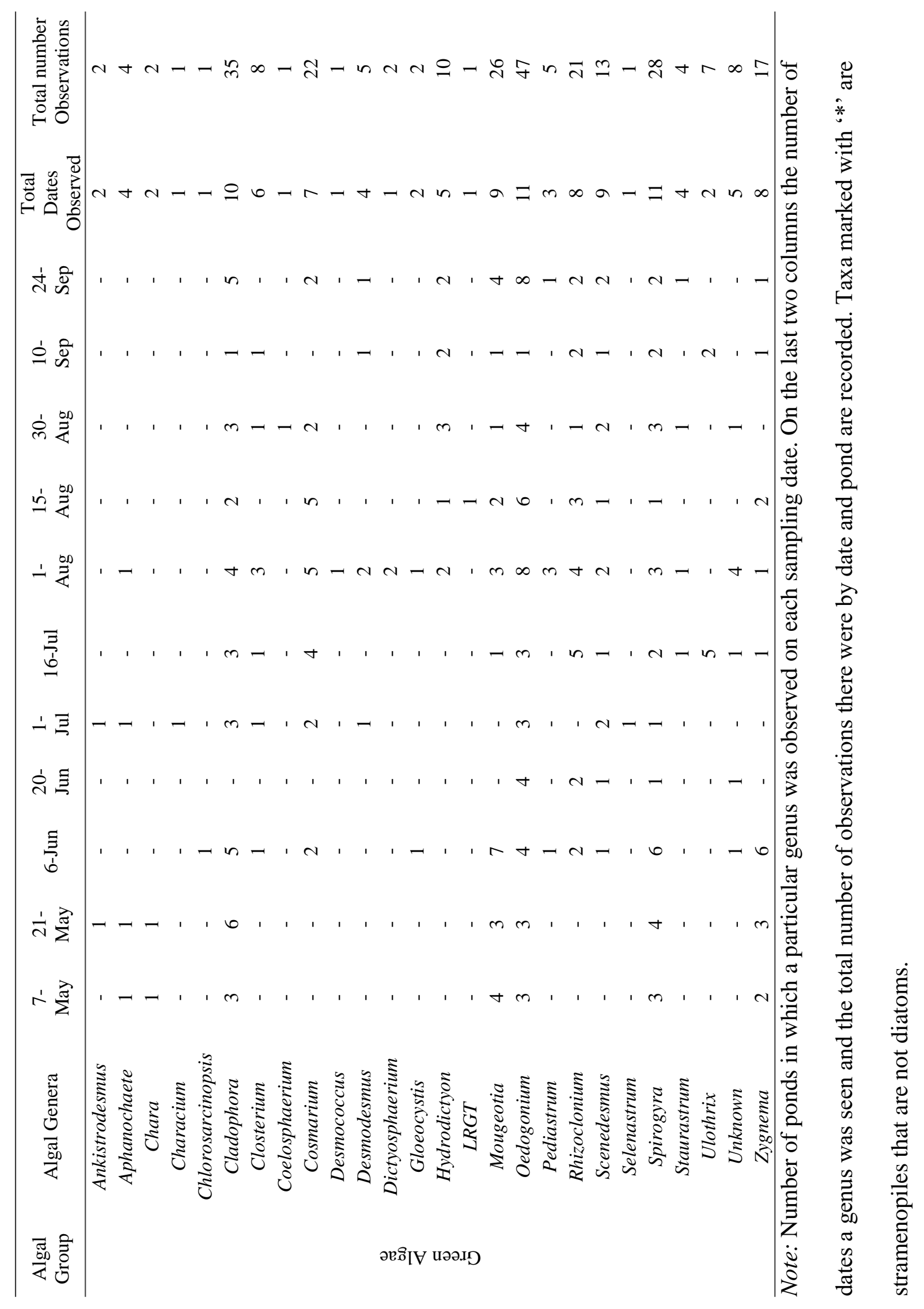




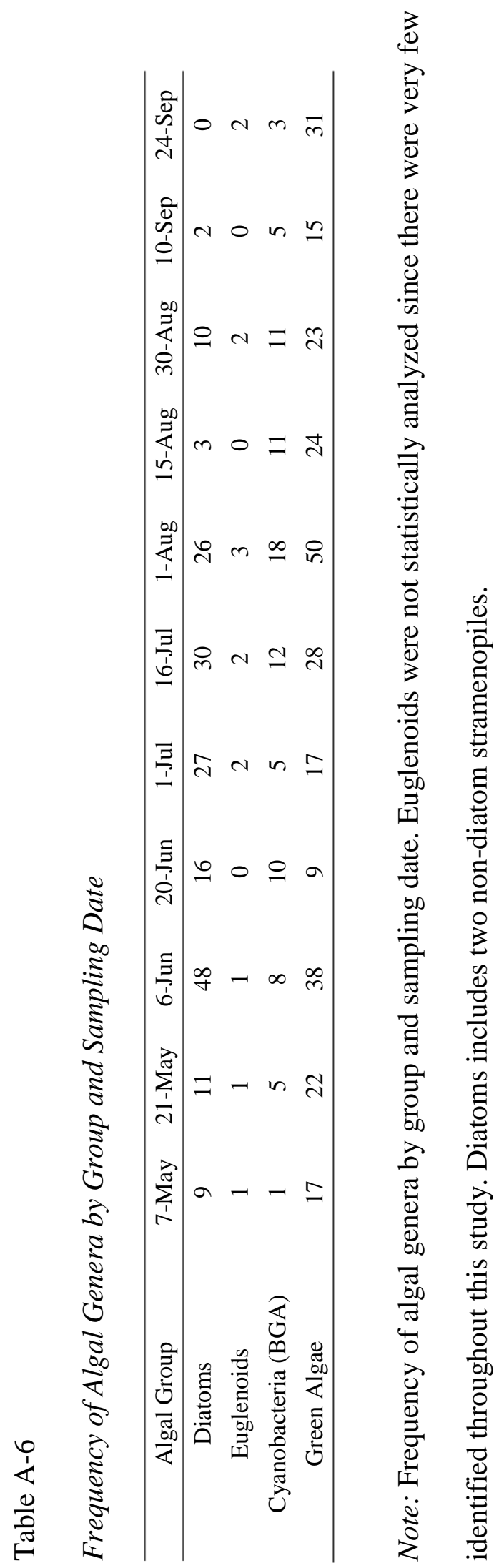




\section{APPENDIX B: POND AND WATERSHED MAPS}

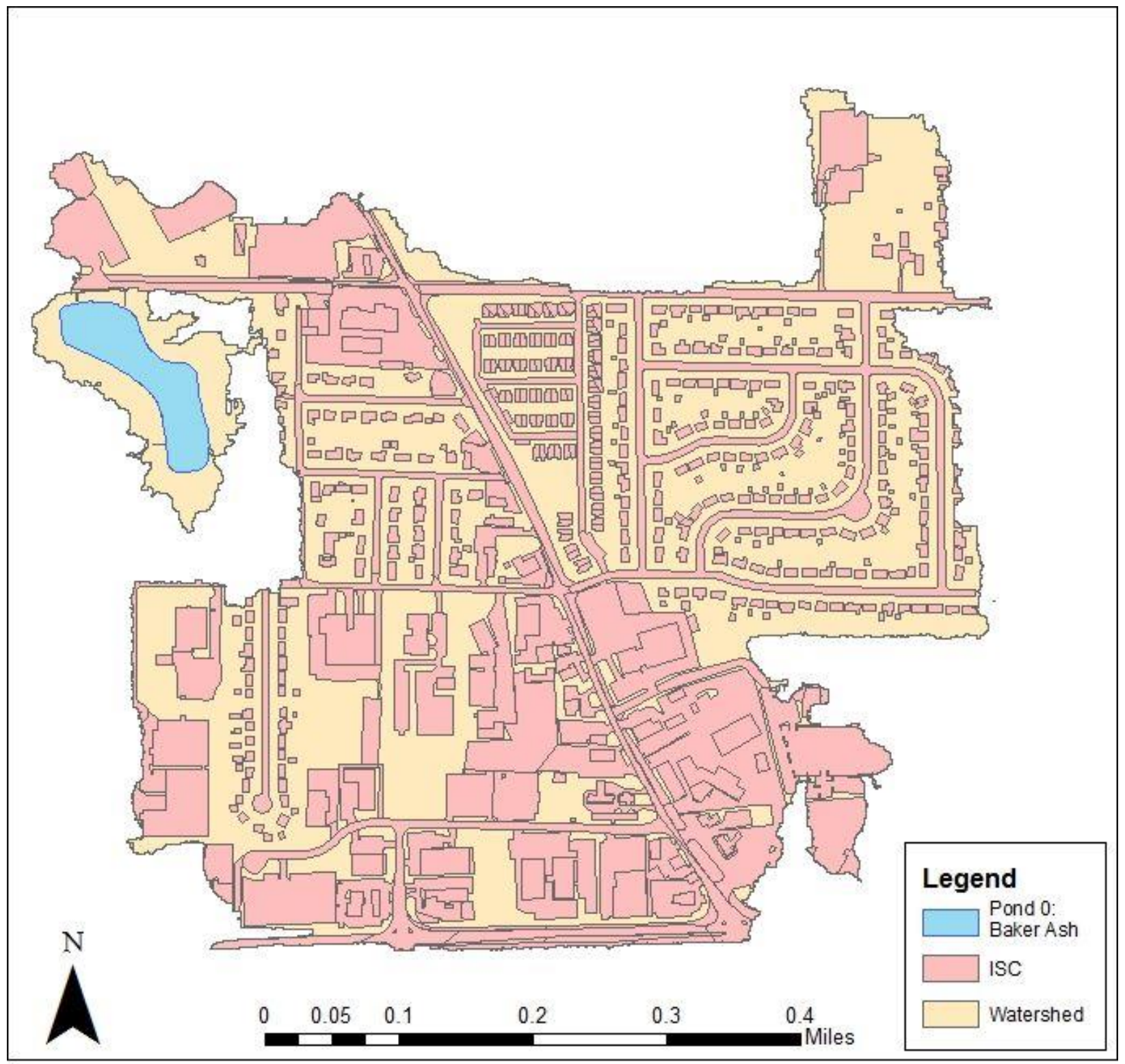

Figure B-1. Pond 0: This map shows the total watershed area contributing to the pond. The total watershed area is $742,757 \mathrm{~m}^{2}$ (Table 1). The impervious surfaces for this entire area are shown in pink and account for $60 \%$ of the land area within the watershed. This pond is located in the southern area of town in a mostly residential and commercial area. 


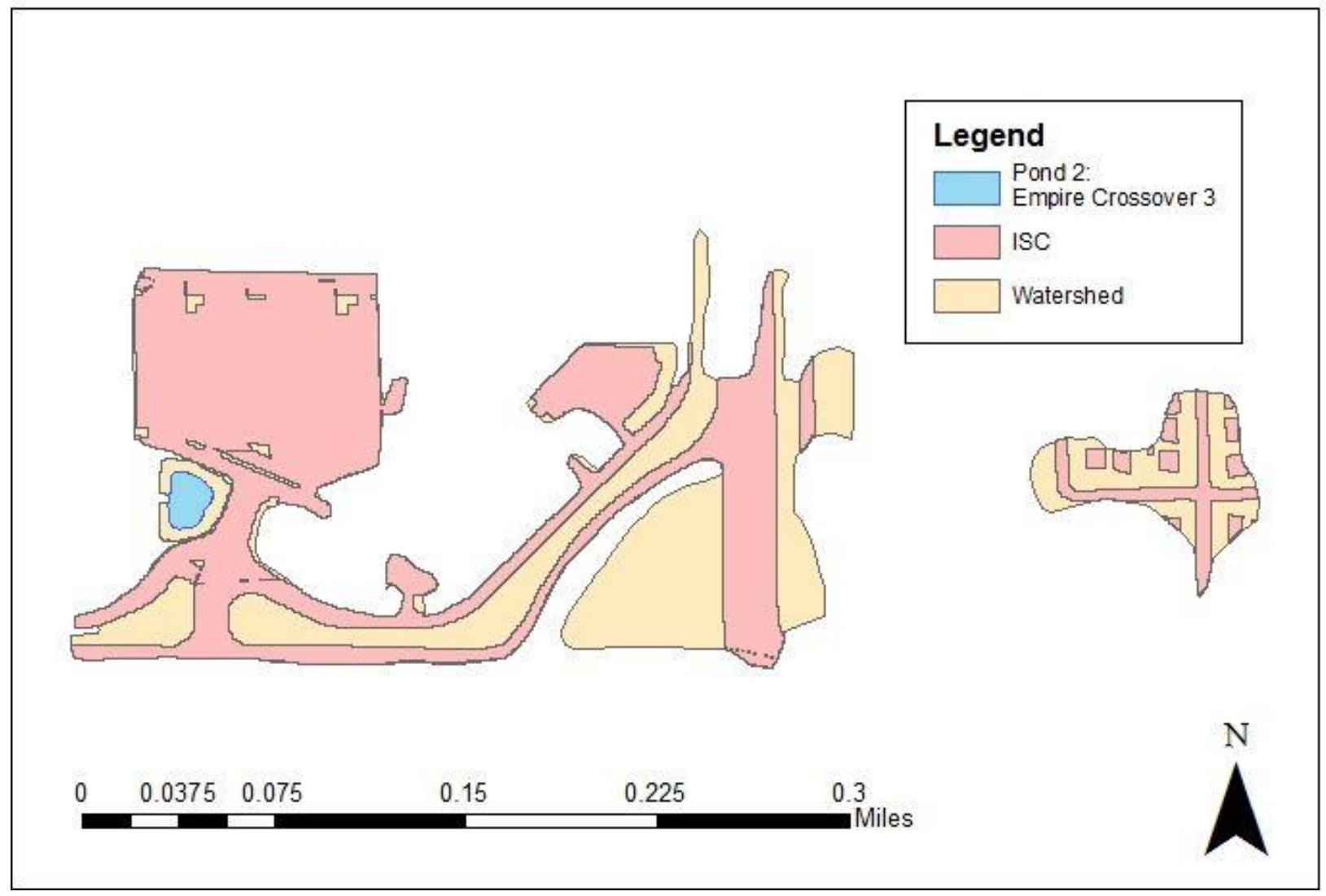

Figure B-2. Pond 2: This pond's watershed was digitized manually due to errors in watershed delineation. The $74,151 \mathrm{~m}^{2}$ of total watershed are of this pond is shown and $60 \%$ of the area is impervious surface. This pond is located centrally in town in a mostly commercial area with high impervious surface. 


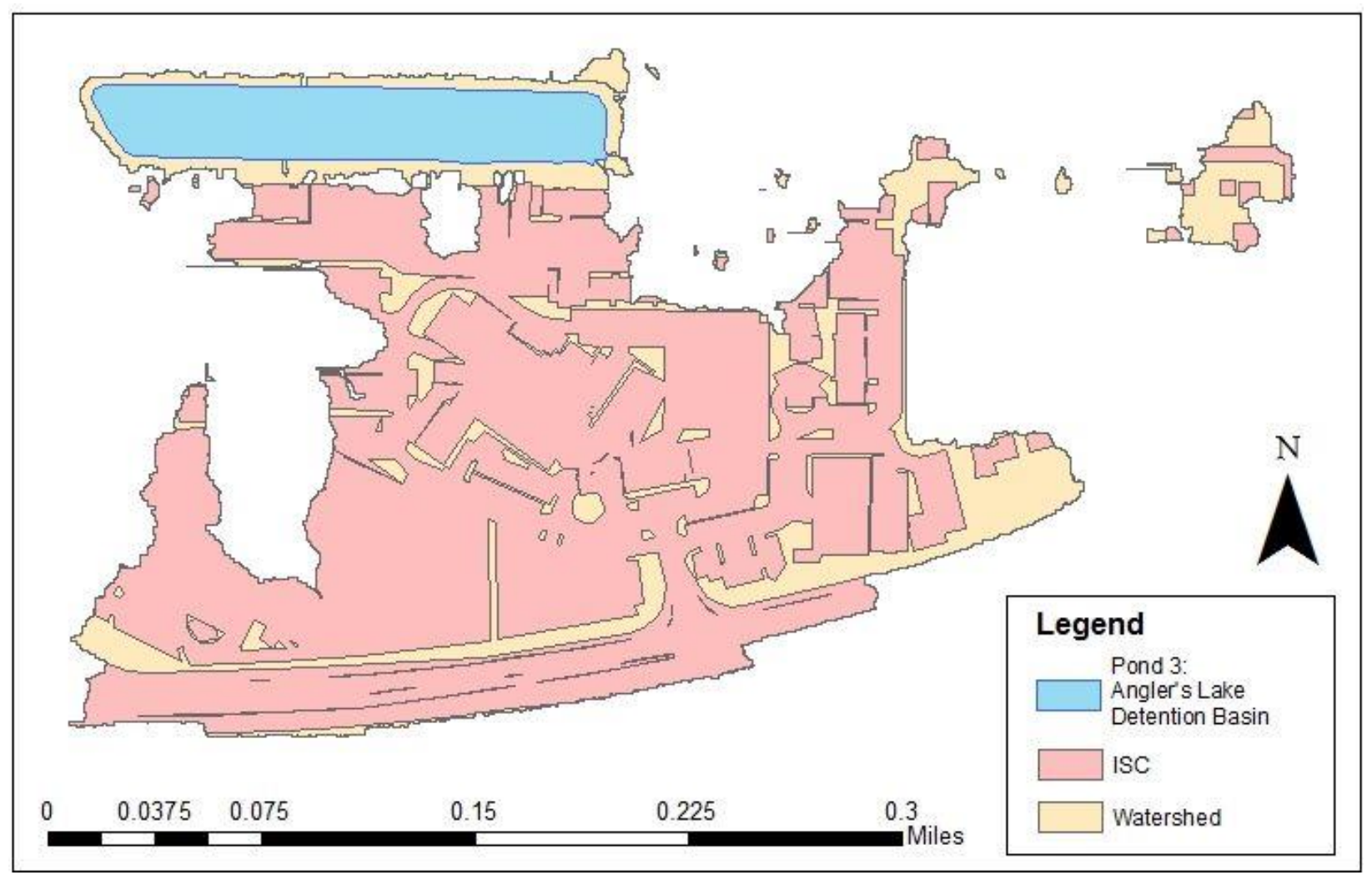

Figure B-3. Pond 3: This pond has a total watershed area of $116,681 \mathrm{~m}^{2}$ (Table 1). The impervious surface accounts for $76 \%$ of the land area within the watershed. Pond 3 is located in the southern area of town with a mix of residential and commercial areas draining into it. 


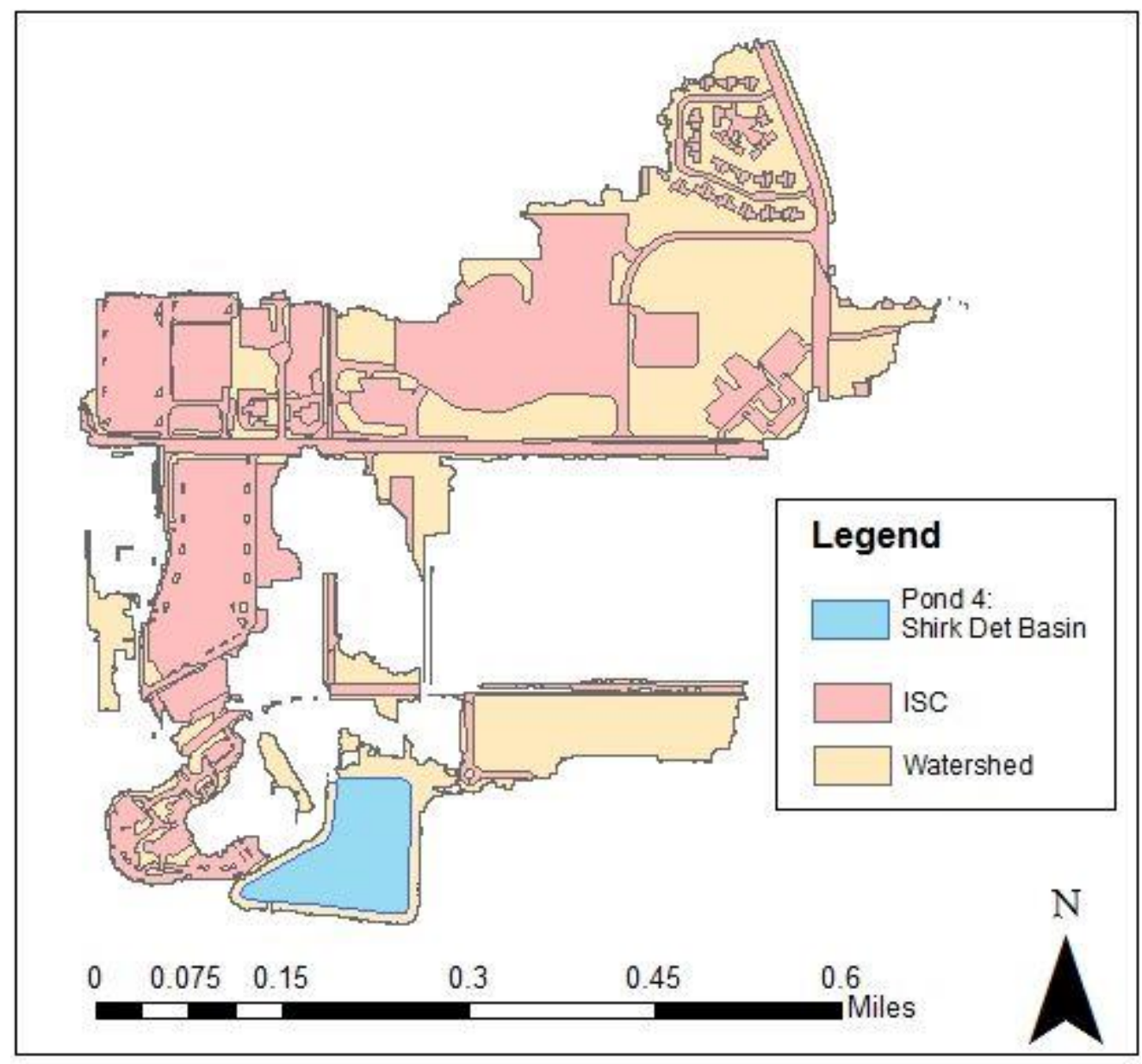

Figure B-4. Pond 4: This pond has a total watershed area of $437,179 \mathrm{~m}^{2}$ and $53 \%$ of these pixels are impervious surfaces (Table 1). This pond is located east of town in a mostly commercial area. 


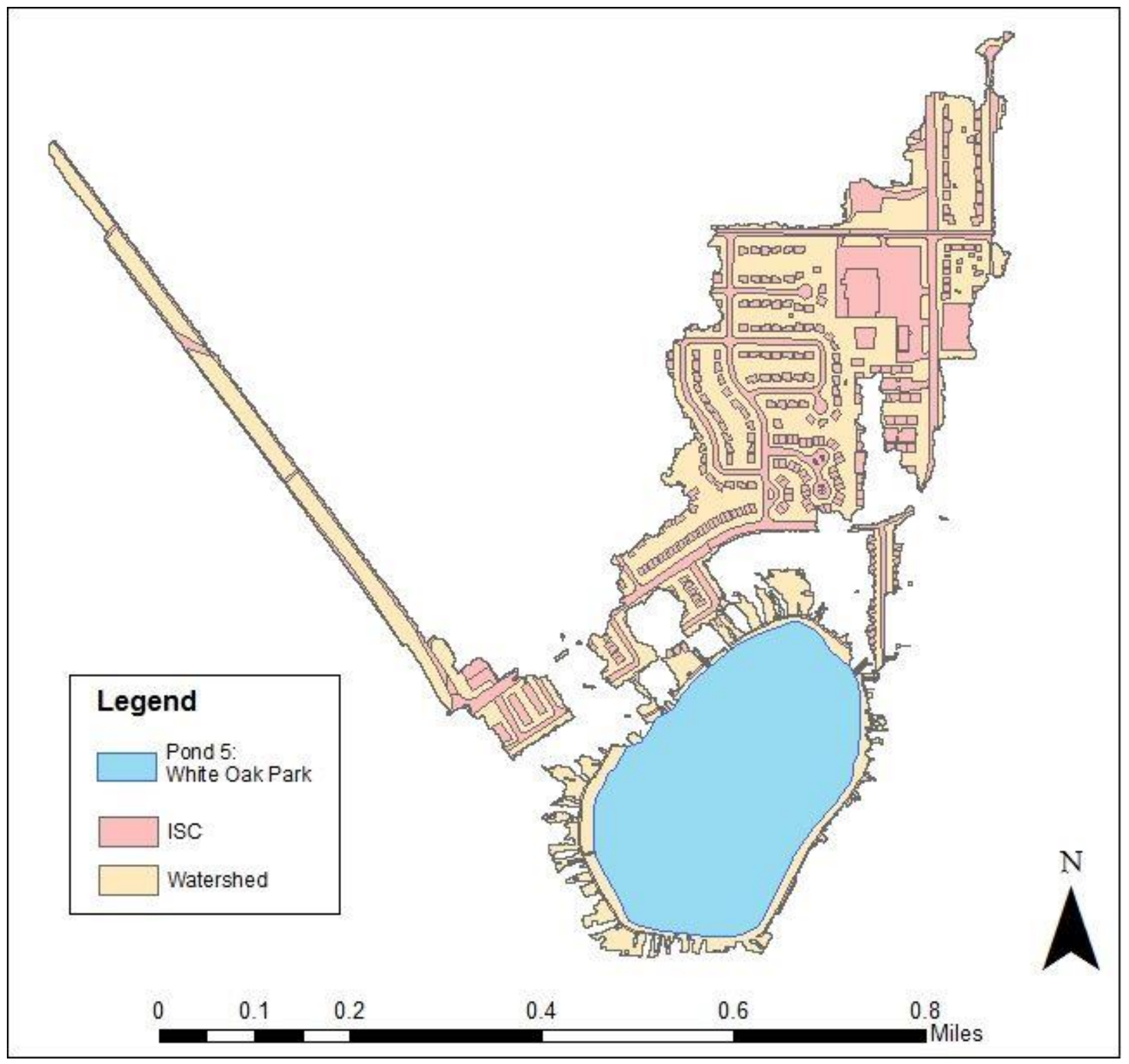

Figure B-5. Pond 5: This pond has a total watershed area of $405,394 \mathrm{~m}^{2}$ and $35 \%$ of the watershed area are impervious surfaces (Table 1). This pond is located in a mostly residential area with a park surrounding the border of it. 


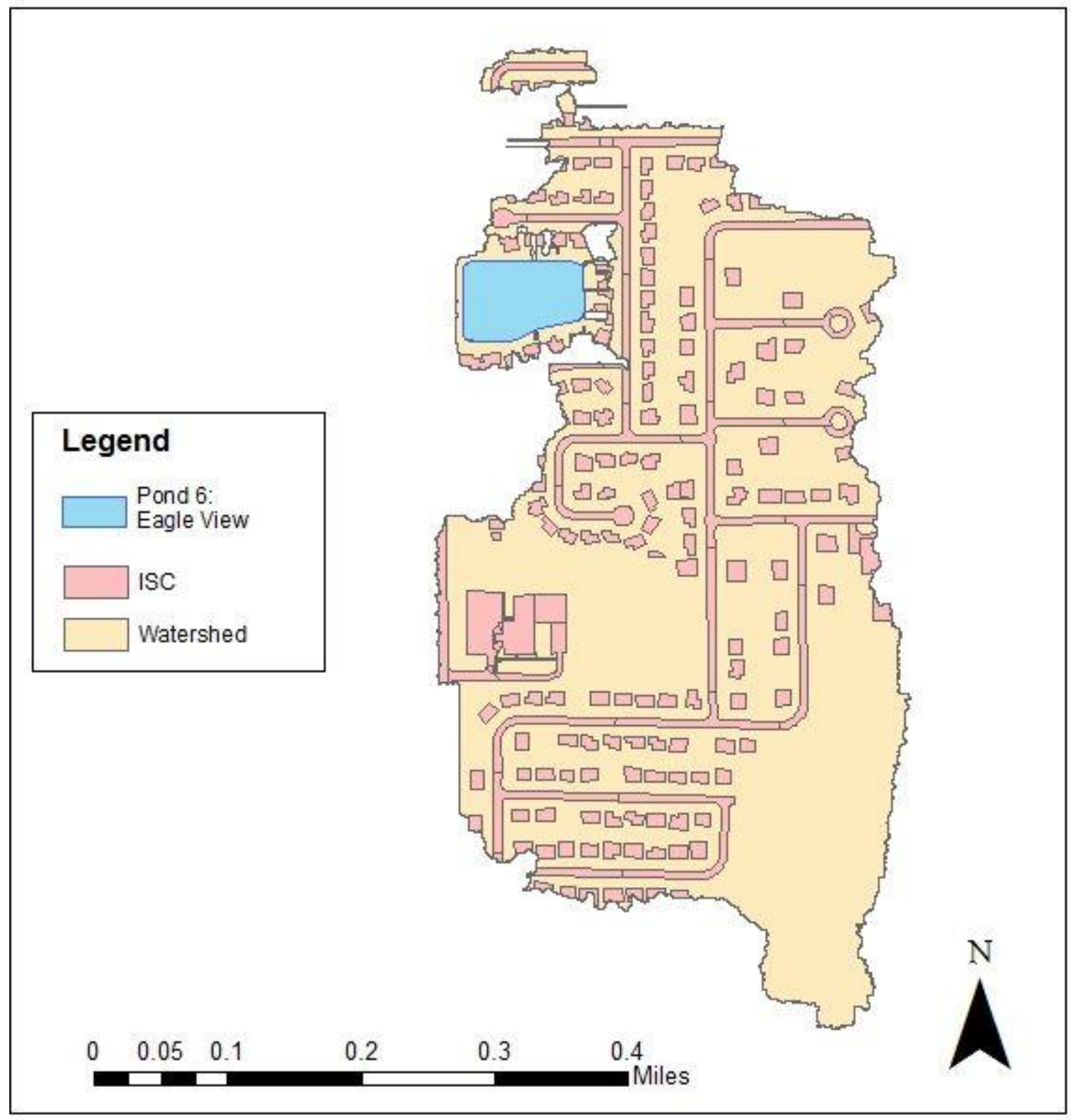

Figure B-6. Pond 6: This pond has a total watershed area of $421,346 \mathrm{~m}^{2}$ of which $23 \%$ of them are impervious surfaces (Table 1). This pond is located northeast of town in a newly developed residential area. 


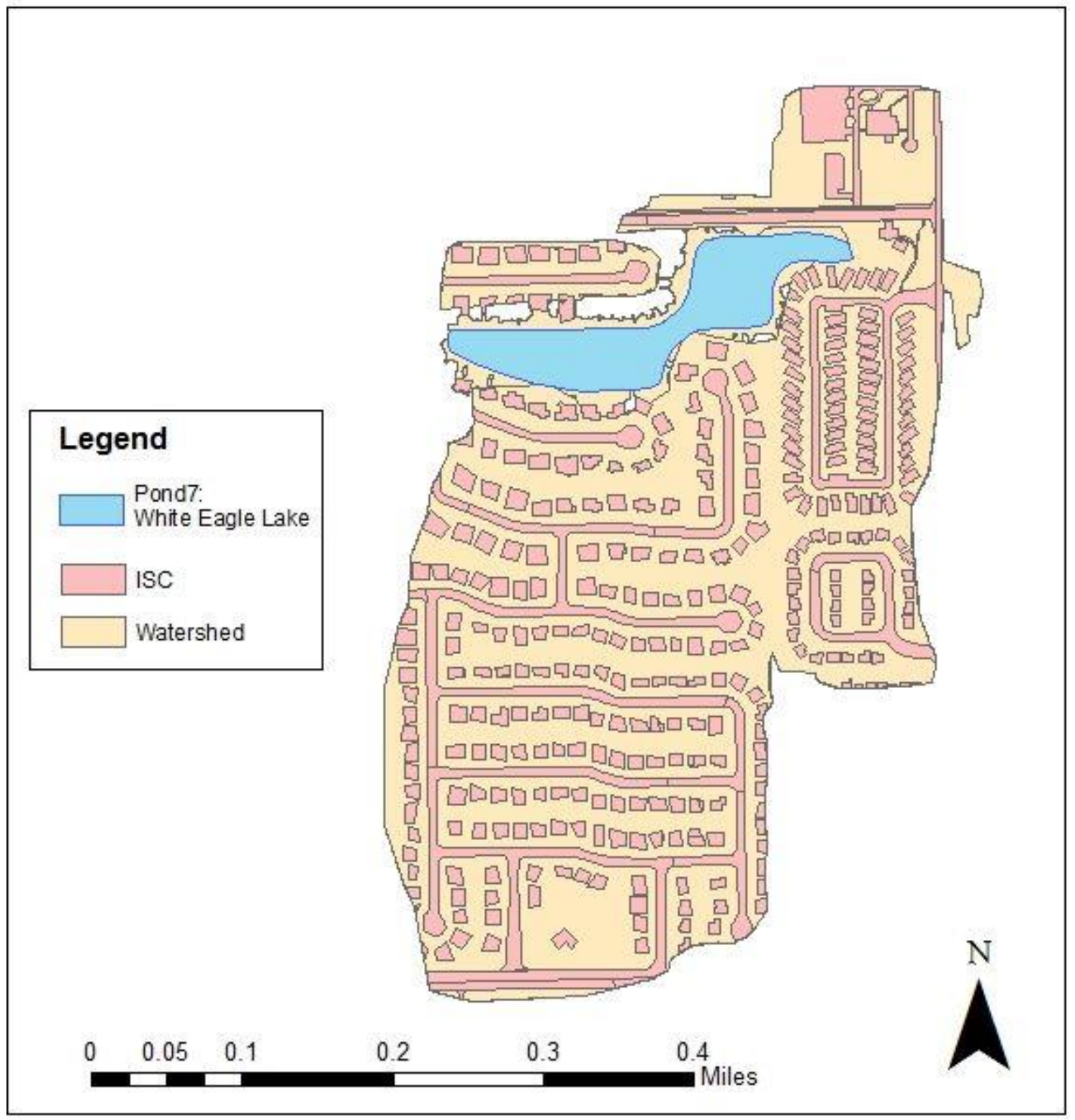

Figure B-7. Pond 7: This pond has a total watershed area of $385,474 \mathrm{~m}^{2}$, which includes $33 \%$ impervious surface area (Table 1). This pond is located southeast of town and directly west of the airport. The land surrounding airport runways grows crops on the land surrounding the perimeter and drains into a pond that then drains into this pond. This pond is located in a residential area, but may also be having agricultural influences. 


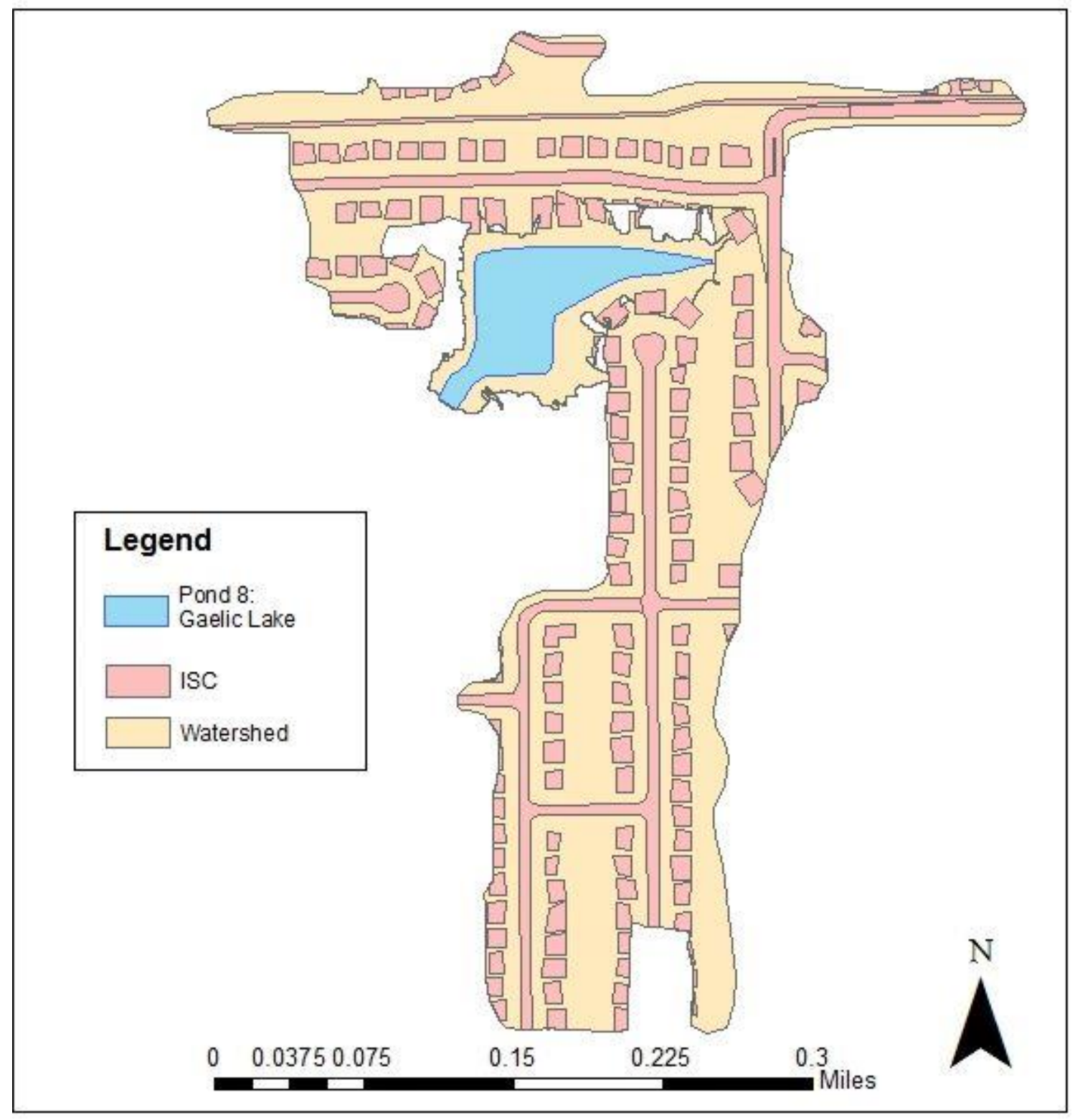

Figure B-8. Pond 8: The total watershed area for this pond is $170,107 \mathrm{~m}^{2}$ and of the watershed, $32 \%$ is comprised of impervious surfaces (Table 1). Pond 7 drains into this pond. The land area around this pond is mostly residential but also has agricultural inflow as well. 


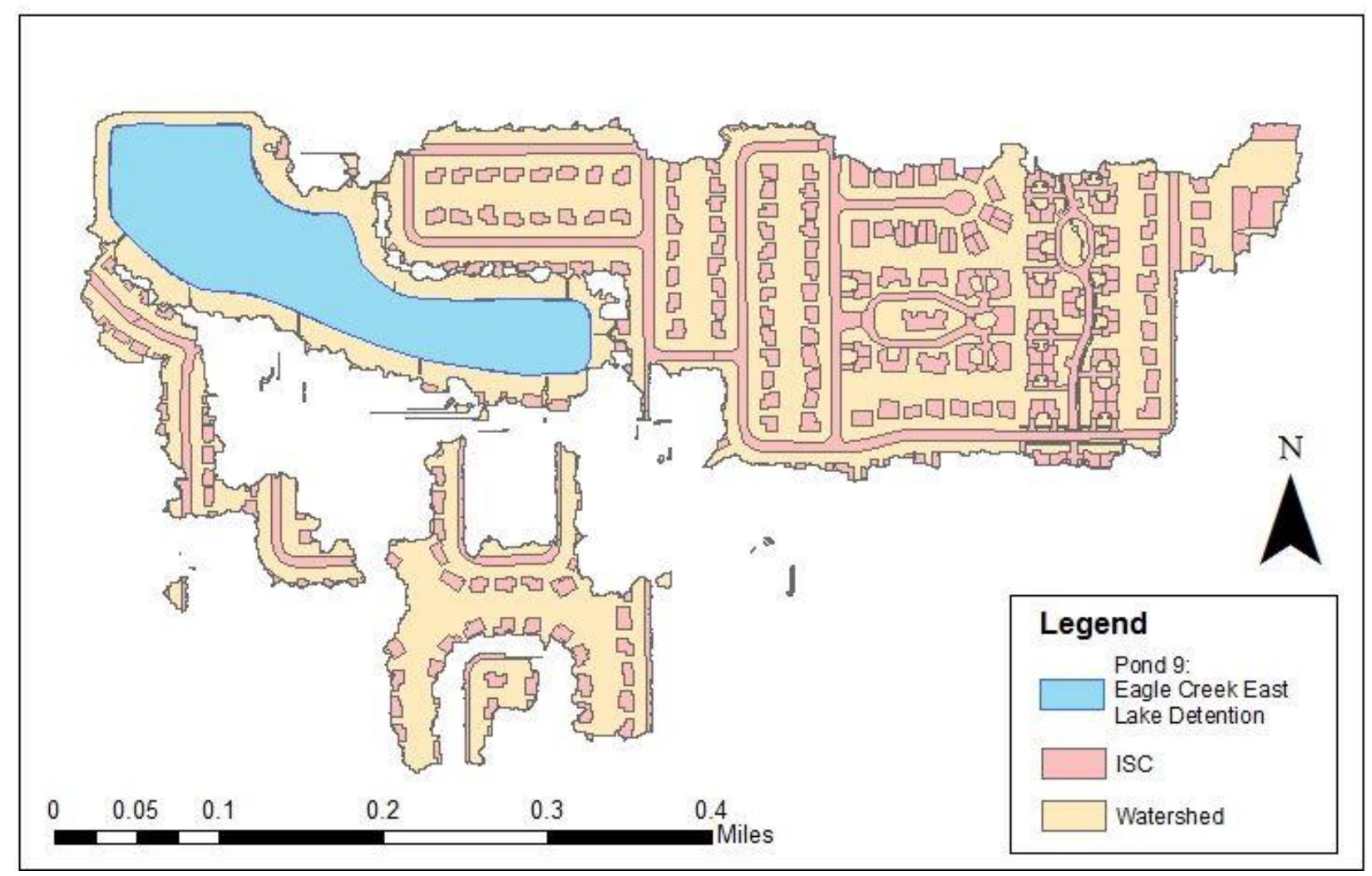

Figure B-9. Pond 9: This pond has a watershed area of $289,285 \mathrm{~m}^{2}$ and includes $32 \%$ impervious surfaces (Table 1). This pond is located in the east part of town in a mostly residential area. 


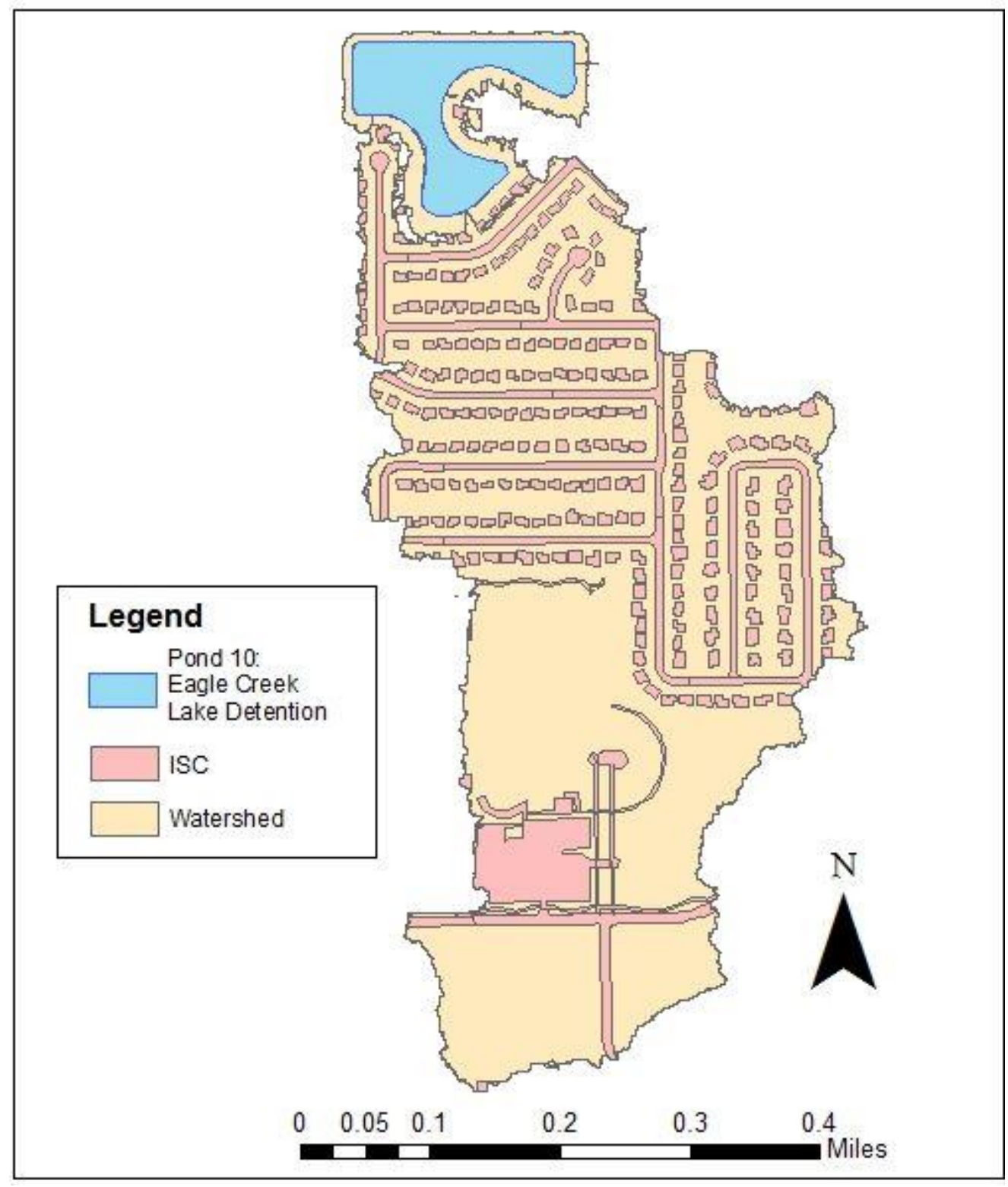

Figure B-10. Pond 10: This pond's total watershed area is $448,633 \mathrm{~m}^{2}$ of which $23 \%$ of the land area in this watershed is impervious surface (Table 1). Pond 9 empties into this pond. Pond 10 is in a residential area on the east side of town. 


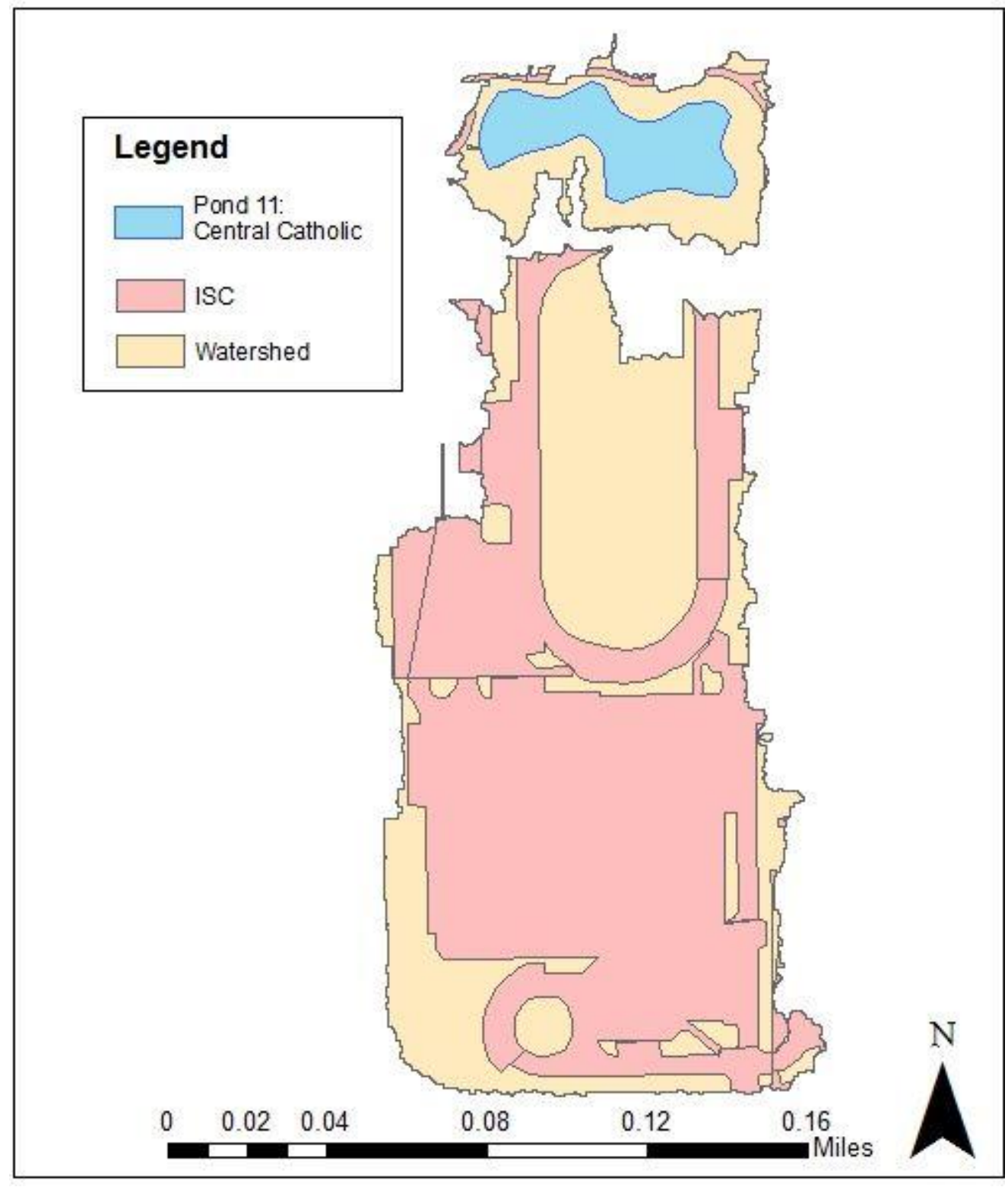

Figure B-11. Pond 11: This pond has a watershed area of $49,143 \mathrm{~m}^{2}$ and $57 \%$ of this area is dominated with impervious surfaces (Table 1). This pond is mostly draining a high school on the east side of town. 


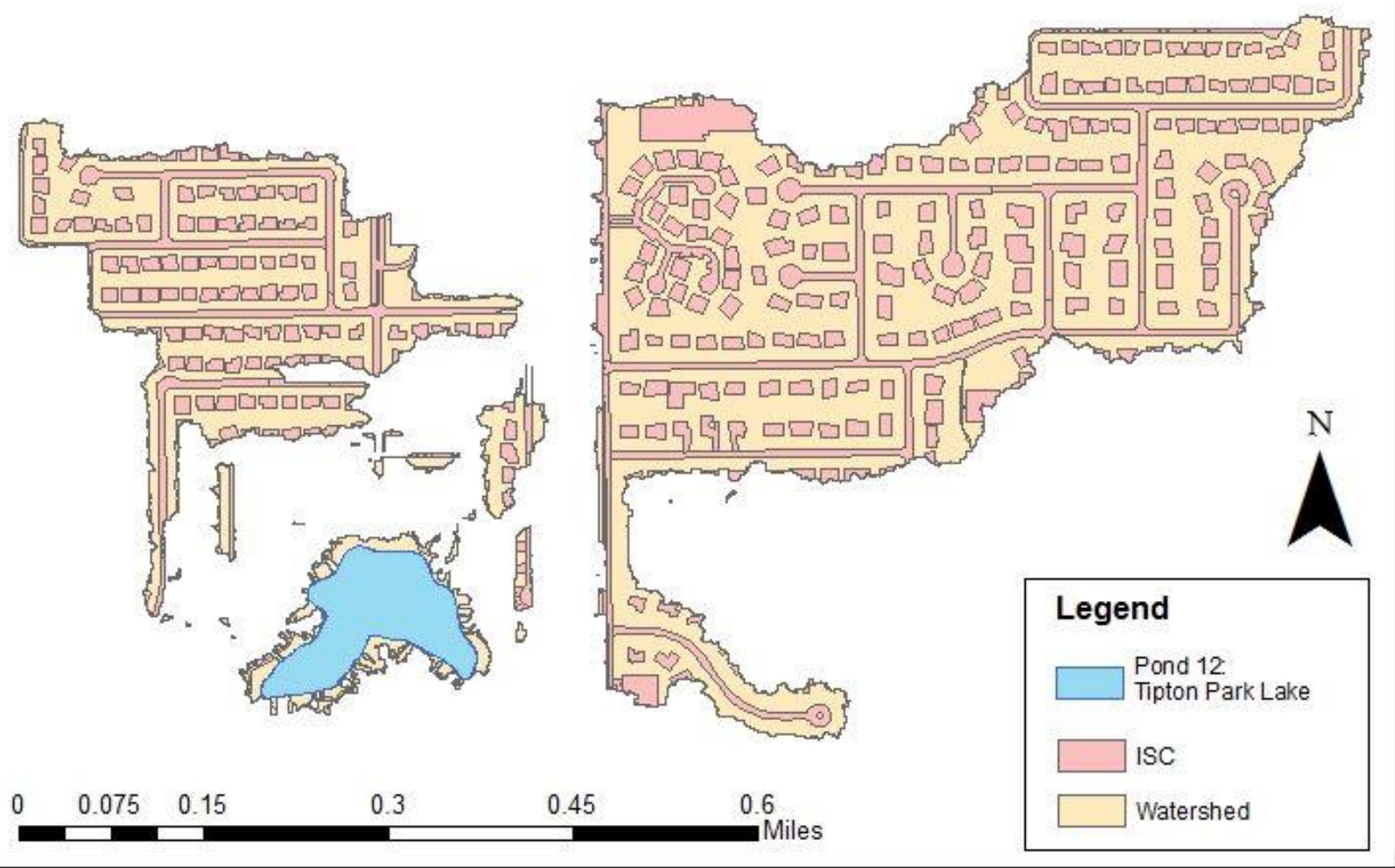

Figure B-12. Pond 12: Pond 12 has a watershed area of $607,179 \mathrm{~m}^{2}$ and includes $34 \%$ impervious surfaces (Table 1). This is a pond in a mostly residential area with a park surrounding it. This pond was once a small stream and has been converted into a park with native vegetation and wetlands. 


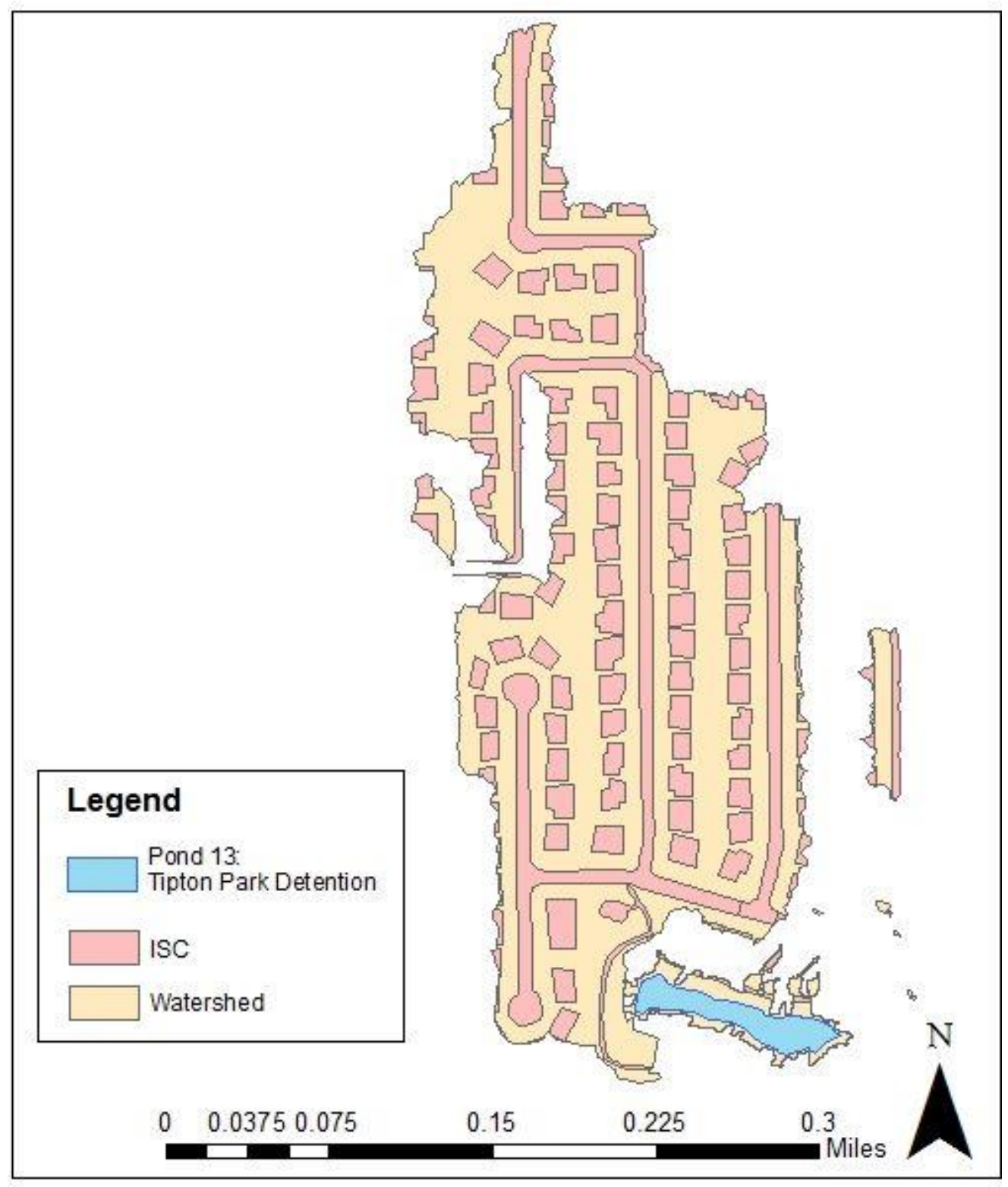

Figure B-13. Pond 13: This pond is in a mostly residential area on the east of town. The watershed area is $133,799 \mathrm{~m}^{2}$ and includes $36 \%$ ISC (Table 1). 


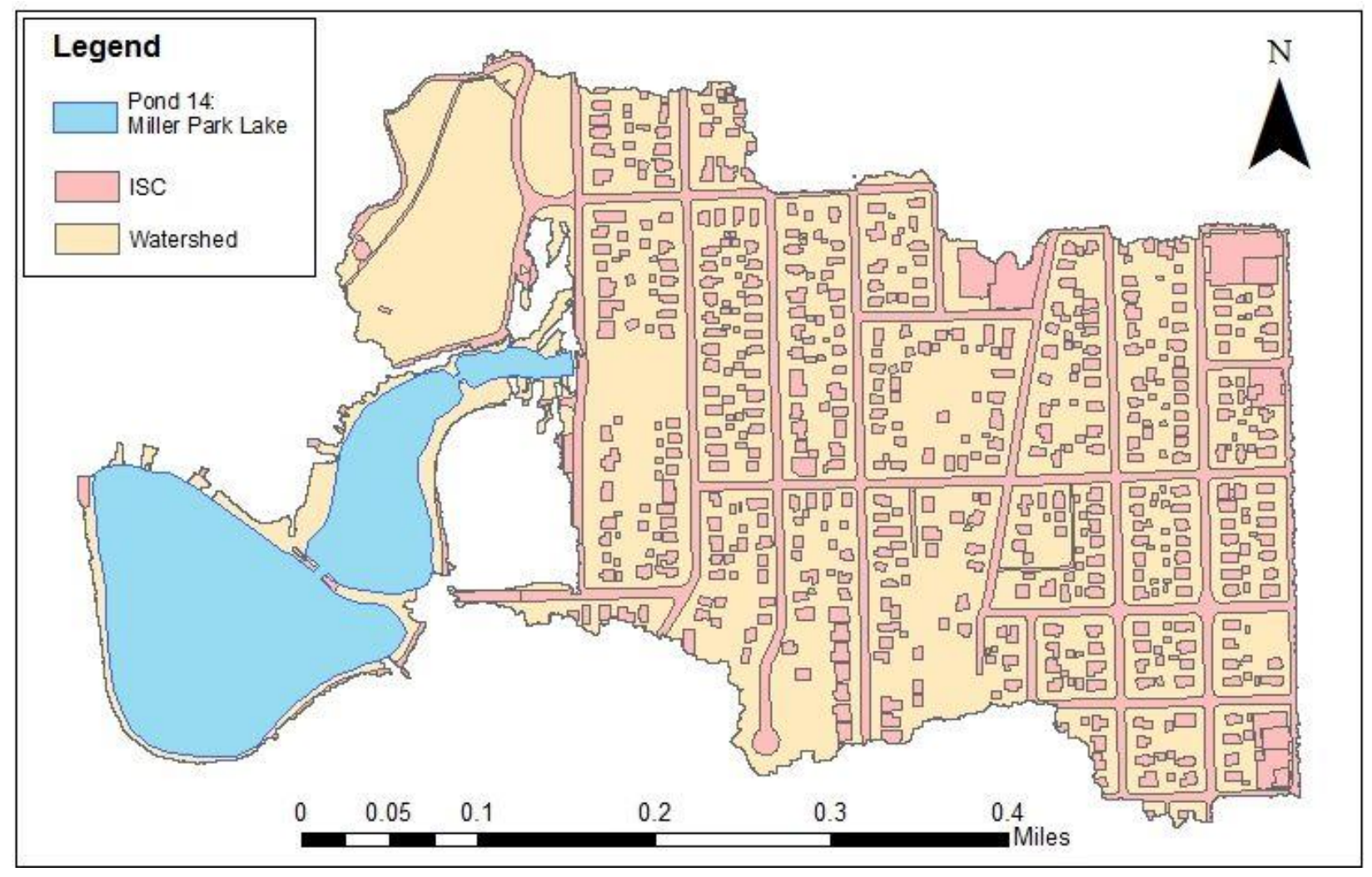

Figure B-14. Pond 14: This pond has a total watershed area of $397,157 \mathrm{~m}^{2}$ and $31 \%$ of the watershed is impervious surface (Table 1). This pond is located next to the zoo in a mostly residential area. 


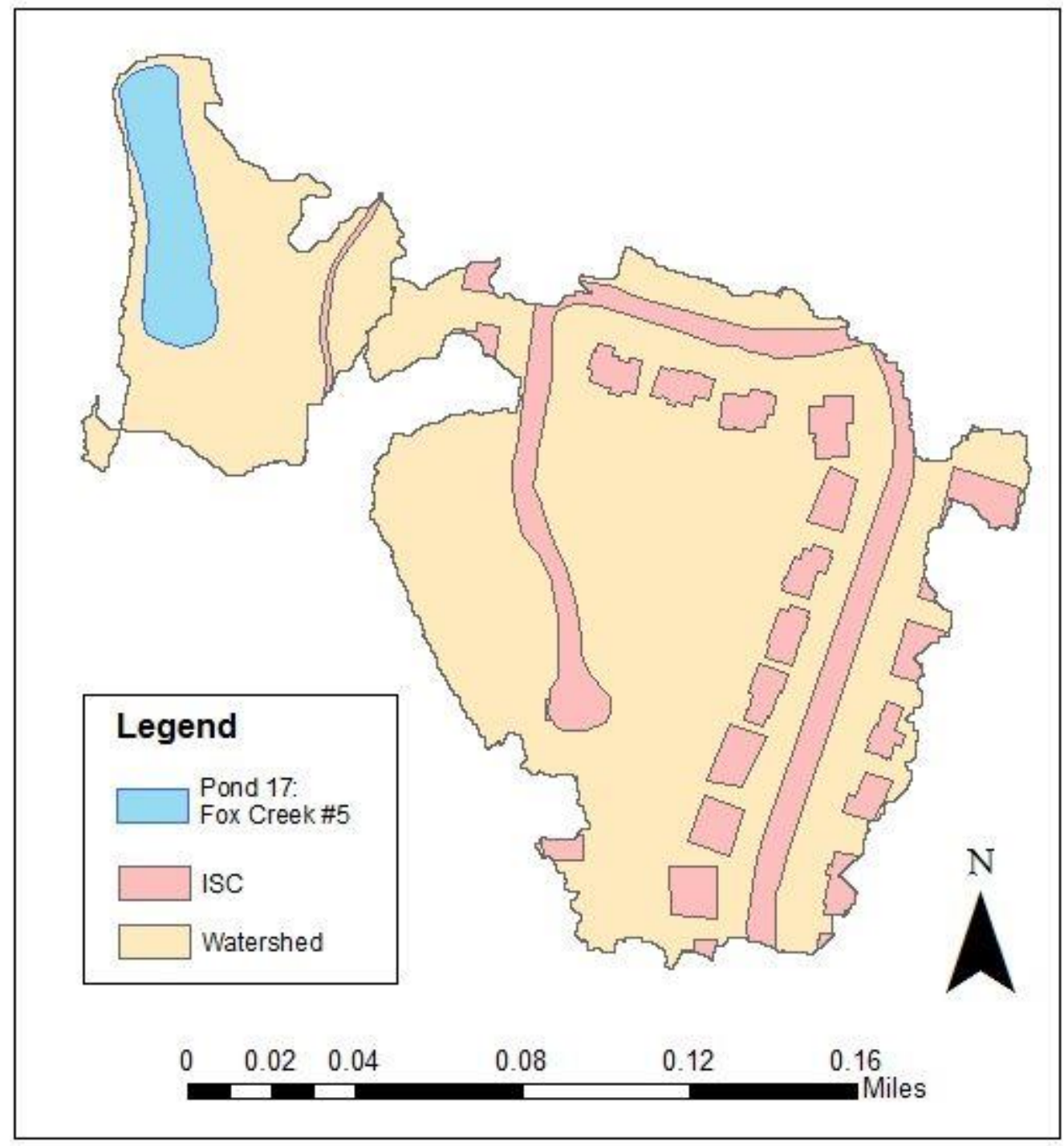

Figure B-15. Pond 17: This pond has a total watershed area of $52,648 \mathrm{~m}^{2}$ and $19 \%$ of it is impervious surface (Table 1). This pond is located southwest of town in a residential area nested on a golf course. 


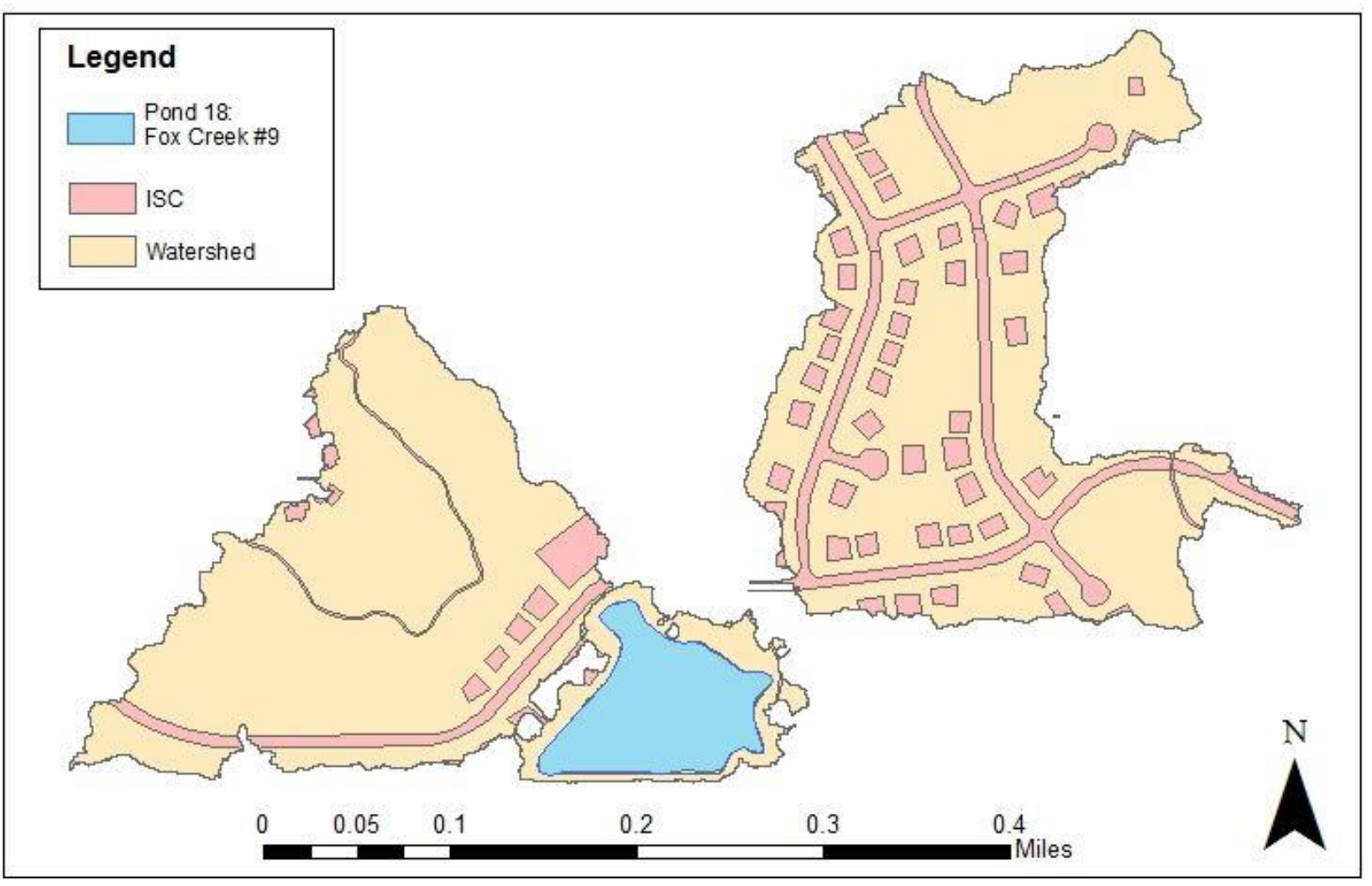

Figure B-16. Pond 18: This pond has a total watershed area of $240,385 \mathrm{~m}^{2}$. The area draining into the pond includes $17 \%$ impervious surfaces (Table 1). This pond is located southwest of town in a residential area nestled on a golf course. 


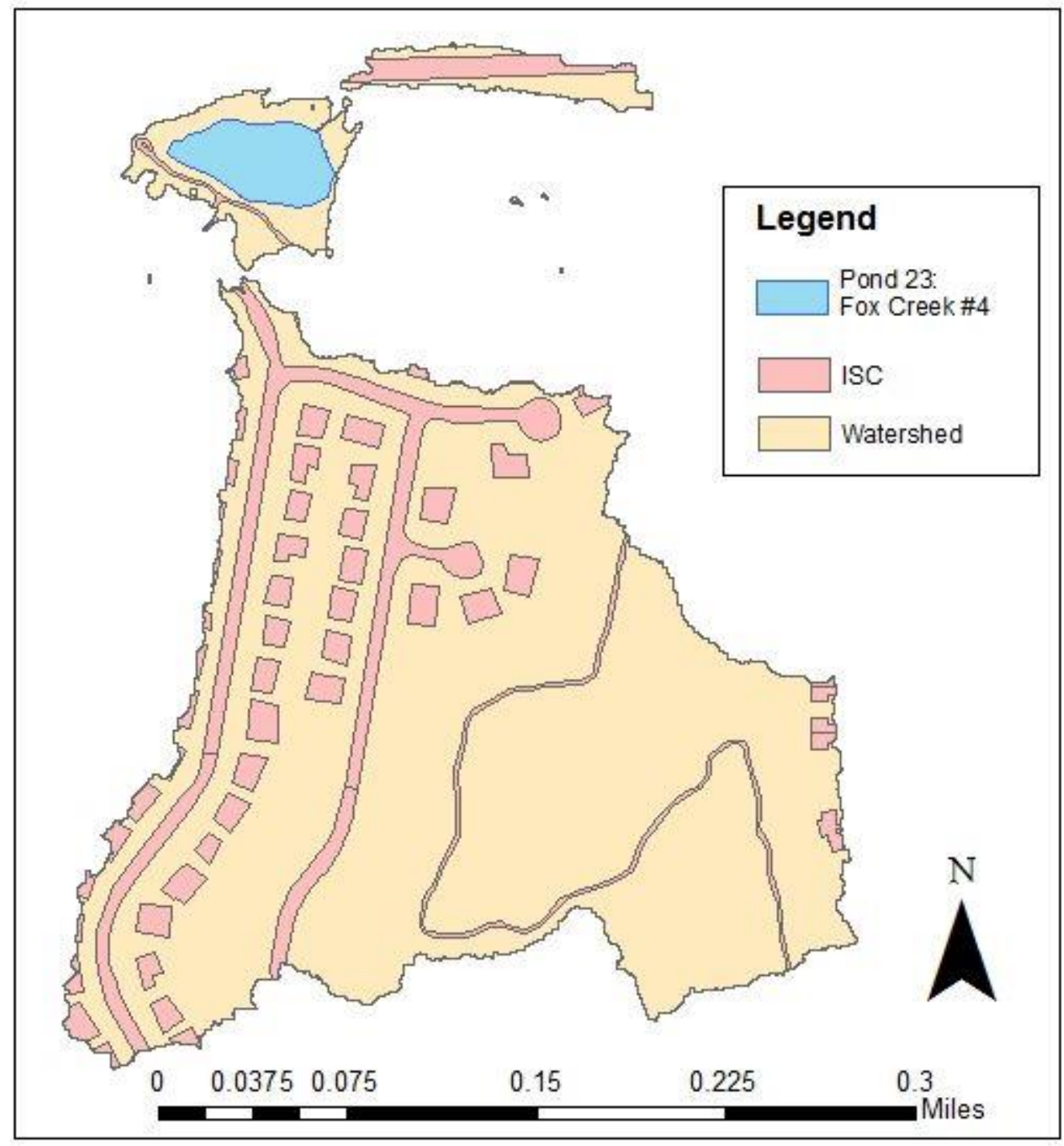

Figure B-17. Pond 23: This pond has a total watershed area of $154,475 \mathrm{~m}^{2}$ and is $18 \%$ impervious surfaces (Table 1). This pond is located in a residential area located on a golf course. 


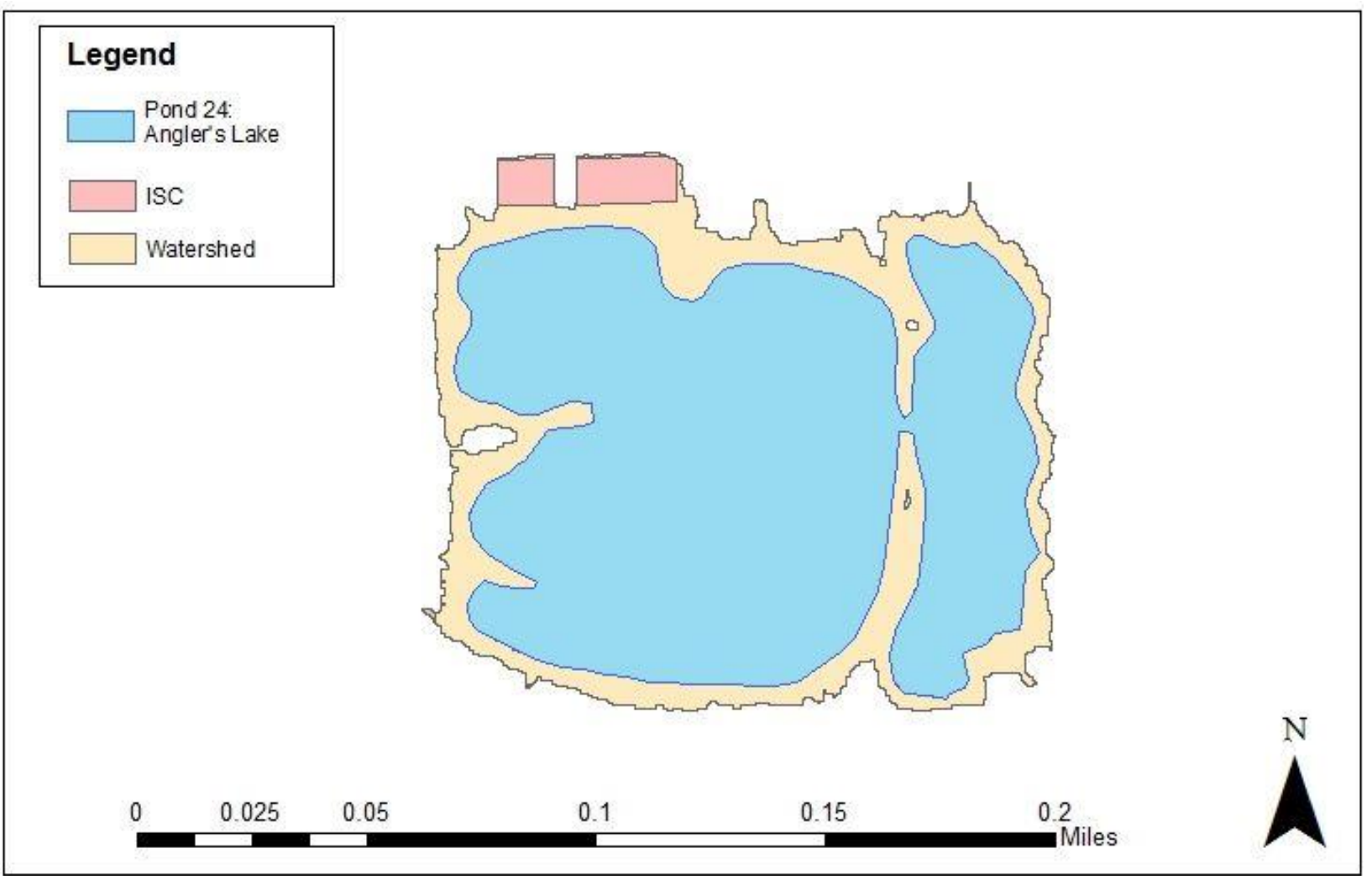

Figure B-18. Pond 24: This pond has a total watershed area of $9,952 \mathrm{~m}^{2}$ (Table 1). There is no storm sewer system associated with this pond. This means there is no sewershed. There is only 9.12\% impervious surfaces within this watershed. This pond is located on the south end of town located in a residential and commercial mixed area. 